\title{
Interrelationship of Indoor particulate matter and Respiratory dust deposition of women in the residence of Dhanbad City, India
}

\section{SHRAVAN KUMAR}

IITISM: Indian Institute of Technology

Manish Kumar Jain ( $\square$ manishjkm@gmail.com )

IITISM: Indian Institute of Technology https://orcid.org/0000-0001-9898-0382

\section{Research Article}

Keywords: Household Air Pollution, Women's health, size segregated PM, RDDs, Exposure Index, Hazard Quotient

Posted Date: May 11th, 2021

DOI: https://doi.org/10.21203/rs.3.rs-446710/v1

License: (c) (1) This work is licensed under a Creative Commons Attribution 4.0 International License.

Read Full License

Version of Record: A version of this preprint was published at Environmental Science and Pollution Research on August 19th, 2021. See the published version at https://doi.org/10.1007/s11356-021-15584W. 
1 Interrelationship of Indoor particulate matter and Respiratory dust deposition of women

2 in the residence of Dhanbad City, India.

3 Authors name: Shravan Kumar ${ }^{1}$, Manish Kumar Jain*2

4

5

6

7

8

9

10

11

12

13

14

15

16

17

18

19

20

21

22

23

24

25

1. Research Scholar, Department of Environmental Science and Engineering, IIT(ISM) Dhanbad, Jharkhand 826004, India

2. Associate Professor, Department of Environmental Science and Engineering, IIT(ISM) Dhanbad, Jharkhand 826004, India

*Corresponding author's Email id: manishjkm@gmail.com Ph no.: 9431711095

(1)


Abstract

27

Women spend relatively more time in indoor conditions in developing countries. Exposure to various indoor air pollutants leads them to higher health risks according to Household air quality in which they reside. Particulate matter (PM) exposure with their exposure duration inside the household plays a significant role in women's Respiratory problems. We measured size segregated particulate matter concentrations in 63 residences at different locations. Respiratory dust depositions (RDDs) for 118 women in their different respiratory regions like head-airway (HD), tracheobronchial (TB), and alveolar (AL) region for the three PM size fractions ( $\left.\mathrm{PM}_{10}, \mathrm{PM}_{2.5} \& \mathrm{PM}_{1}\right)$ were investigated. For different positions like Light exercise and the Sitting condition, RDD values found for AL region was $0.091 \mu \mathrm{gmin}^{-1}$ (SD: 0.067, $0.012-0.408$ ) and $0.028 \mu \mathrm{gmin}^{-1}$ (SD: $\left.0.021,0.003-0.126\right)$ for $\mathrm{PM}_{10}, 0.325 \mu \mathrm{gmin}^{-1}$ (SD: 0.254, $0.053-1.521$ ) and $0.183 \mu \mathrm{gmin}^{-1}$ (SD: 0.143, 0.031-0.857) for $\mathrm{PM}_{2.5}, 0.257 \mu \mathrm{gmin}^{-1}$ (SD: 0.197, 0.043-1.04) and $0.057 \mu \mathrm{gmin}^{-1}$ (SD: $0.044,0.009-0.233$ ) respectively for $\mathrm{PM}_{1}$ to females. RDDs values in the AL region significantly increases as $\mathrm{PM}_{10}(11 \%), \mathrm{PM}_{2.5}(68 \%)$, and $\mathrm{PM}_{1}$ (21\%), confirm that for women, the AL region is the most prominent affected zone by fine particles $\left(\mathrm{PM}_{2.5}\right)$.

Keywords -Household Air Pollution, Women's health, size segregated PM, RDDs, Exposure Index, Hazard Quotient,

List of abbreviations: PM: Particulate matter, HAP: Household air pollution, RDDs: Respiratory dust depositions, HD: Head airway, TB: Tracheobronchial, AL: Alveolar, I/O: indoor-outdoor, EI: Exposure index, HQ: Hazard Quotient 


\section{INTRODUCTION}

Household Air Pollution (HAP) is prevalent in developing countries like India, but its resultant impact is detrimental for all, and therefore, it is a significant area of study (Smith 2000; Smith and Mehta 2003). HAP negatively impacts the health and life quality of individuals. The health risks associated with HAP include respiratory problems and premature deaths (Beelen et al. 2014a). HAP is among those leading environmental pollutants, which causes risk factors and increases the global burden of disease. It has been accountable for 1.6 million deaths and 59 million disability-adjusted life years in 2017 (Stanaway et al. 2018). Africa and Southeast Asian countries are the most affected nations due to the rise of HAP exposure in the developing world (WHO 2011). HAP depends on many variables such as the type of fuel that is being used for cooking, various kitchen facilities, household structural features, house ventilation, smoking history, house location, geographical conditions, and various other activity patterns within that period of exposure (Wu et al. 2007; Begum et al. 2009; Pant et al. 2016; Sidhu et al. 2017; Datta et al. 2017; Rohra et al. 2018; Prabhu et al. 2019a; Benka-Coker et al. 2020). For cooking purposes, people in India use mainly two fuel types (The Census of India 2011). Solid fuels commonly consist of coal, cow dung cake, wood, crop residue, and in clean fuels, primarily electricity and Liquefied Petroleum Gas (LPG) (Pandey and Chaubal 2011; Sidhu et al. 2017). An estimated population of about $28 \%$ of India's urban population engages in biomass fuels for cooking (The Census of India 2011; Bhole 2017). A survey by the Health Effect Institute (HEI) estimated 1.8 million premature deaths and 48.7 million disabilityadjusted life years (DALYs) due to HAP exposure in India (GBD MAPS Working Group, 2018) (Sharma and Jain 2019).

In the Indian scenario, Particulate Matter (PM) is of significant concern for HAP. PM affects the microenvironment and contributes to escalating a significant particulate dose amount in the ambient atmosphere (Kesavachandran et al. 2015; Kumar and Goel 2016a). In 2010, HAP accounted for $16 \%$ of the total ambient PM concentration (Hime et al. 2018). The burning of fuels for cooking purposes generates a substantial PM level, which significantly affects its surrounding population in both urban and rural regions (Smith and Mehta 2003; Fullerton et al. 2008; de la Sota et al. 2018). Aerodynamic diameter is the key point for PM size fractions. Particles classified as thoracic $\left(\mathrm{PM}_{10}\right.$, particles size $\left.<10 \mu \mathrm{m}\right)$, coarse $\left(\mathrm{PM}_{2.5-10}, 2.5 \mu \mathrm{m}<\right.$ particles size $<10 \mu \mathrm{m})$, fine $\left(\mathrm{PM}_{2.5}\right.$ and $\mathrm{PM}_{1}$, particles size $\left.<2.5 \mu \mathrm{m}\right)$ and ultra-fine particles (particles size $<0.1 \mu \mathrm{m}$ ) (Daigle et al. 2003; Singh et al. 2015a; Kesavachandran et al. 2015). Exposure of fine particles $\left(\mathrm{PM}_{2.5}\right)$ to long term reflects the curtailment from 8.5 to 20 months in average life 
expectancy, and increment in the cardiopulmonary mortality risk by $6-13 \%$ per $10 \mathrm{mg}$ per cubic meter of $\mathrm{PM}_{2.5}$ (Evans et al. 2013; Datta et al. 2017). Extended exposure to PM, particularly to the fine and ultrafine particles, elevates the risk for health disorders like respiratory infections, aggravation of chronic lung diseases, heart problems, stroke, eye inflammation, tuberculosis, and cancer (Smith 2000; Balakrishnan et al. 2013; Singh et al. 2015b; Stanaway et al. 2018). Many studies have linked excessive PM concentrations in households with adverse health effects (Massey et al. 2013; Jindal et al. 2020). In the elderly residents of Sao Paulo (Brazil), $\mathrm{PM}_{10}$ and $\mathrm{PM}_{2.5}$ were measured as 35.2 and $27.4 \mu \mathrm{g} / \mathrm{m}^{3}$ (Segalin et al. 2017). For Kaohsiung City, Taiwan, household $\mathrm{PM}_{10}$ daily average value exceeds 62 $\mu \mathrm{g} / \mathrm{m}^{3}$ (Yen et al. 2020). In various studies, the $24 \mathrm{~h}$ average $\mathrm{PM}_{10}$ concentration was found in between $200-500 \mu \mathrm{g} / \mathrm{m}^{3}$ for households using biomass fuels, depending on multiple parameters like type of fuels, different cooking- stoves, housing structure (Barnes et al. 2011; Beelen et al. 2014b; Adesina et al. 2020). A study (Smith and Mehta 2003) based on $\mathrm{PM}_{2.5}$ concentration in Guatemalan village showed the value exceeded $5000 \mu \mathrm{g} / \mathrm{m}^{3}$. In Nepal, the $\mathrm{PM}_{2.5}$ values crossed $8000 \mu \mathrm{g} / \mathrm{m}^{3}$ for households using an open fire, while it exceeded $3000 \mu \mathrm{g} / \mathrm{m}^{3}$ for homes using Kerosene (Lohani 2011). In Punjab, cooking with biomass fuel resulted in $\mathrm{PM}_{2.5}$ values of up to $697 \mu \mathrm{g} / \mathrm{m}^{3}$ for the household enclosed kitchen (Sidhu et al. 2017).

The vulnerability of different sections of the population to HAP depends on several factors, including their age, gender, surrounding meteorological parameters, socioeconomic conditions, and pre-existing health conditions (Pant et al. 2016; Hime et al. 2018). Previous research (Simoni et al. 2004; Pandey and Chaubal 2011) delineated that women spent unquestionably more time in indoor conditions than men in India. Women are the most vulnerable to HAP as higher levels of exposure due to more residence time in houses (more than 80\%). For women's household chores, cooking is considered the highest share in most countries. In developing countries, females, compared to men, contribute more than 75 percent to cooking activities (Mishra 2003). The Exposure assessment of vulnerable individuals is essential in assessing the possible health risk under various Household air pollutants. This evaluation can be achieved either by personal monitoring or by monitoring the specific area, accompanied by questionnaires survey with different time-activity patterns (Gupta and Elumalai 2017; Sidhu et al. 2017; de la Sota et al. 2018). It can further be established in a particulate dose in the lungs and can be used to understand or predict potential health risks (Sharma and Jain 2019). Very few studies have been recorded on Respiration dust deposition due to PM in women, particularly during cooking in urban household settings, where they mostly use LPG (Varghese 
et al. 2005). Health hazards of increasing household PM concentrations have been discussed in several previous studies (Olmo et al. 2011; Arbex et al. 2012; Morris et al. 2012; Weuve et al. 2012; Mehta et al. 2016; Bai et al. 2020). Notwithstanding, different particle sizes with their exposure dose, duration, and particle deposition behaviour in human bodies, are still required for a comprehensive review. It gives rise to the need for continuous household air quality monitoring.

Air quality is a much-concerned factor for Dhanbad city, popularly known as India's Coal Mining Capital. In the report of the Central Pollution Control Board (CPCB 2009) of India, Dhanbad had been identified as one of the "Critically Polluted Areas." A study (Gupta and Elumalai 2017) of PM conducted found that it can have adverse effects on the people dwelling in the Dhanbad region; also, it gave an alarming result of the respiratory diseases with an

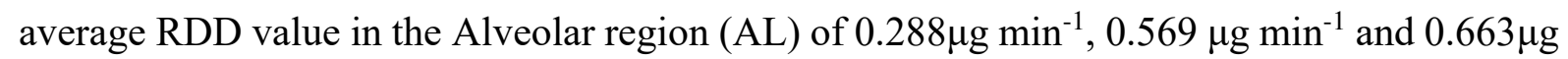
$\min ^{-1}$ for $\mathrm{PM}_{10}, \mathrm{PM}_{2.5}$ and $\mathrm{PM}_{1}$ respectively for women.

Therefore, this present study mainly concentrates on

- Correlating HAP and its associated impacts on Respiratory Dust Depositions (RDDs) of women.

- $\quad$ Evaluating the Exposure Index (EI) and Hazard Quotient (HQ) to determine exposure.

To accomplish these goals, real-time continuous monitoring of the Size segregated PM within the household was carried out, along with different activity patterns records of women within.

\section{Study area and methodology}

\subsection{Sampling site}

Dhanbad is popularly known as the coal-mining capital of India. It is situated in Jharkhand state, having the Jharia coalfield range. Its geographical coordinates are $23.79^{\circ} \mathrm{N}$ and $86.43^{\circ} \mathrm{E}$, respectively. Measurement of particulate matter concentration and particle count was conducted in selected households in the various area represents the suburban residential conditions. We measured outdoor ambient PM concentrations in the surrounding regions for indoor-outdoor interaction. Major selected areas comprise Dhaiya Basti (which was primarily a slum area), IIT(ISM) Dhanbad (a national level institution for Science and Engineering), Hirapur (old city area with mixed Socio-Economical status). Fig 1 depicts the study area locations in the Dhanbad city of Jharkhand State. 

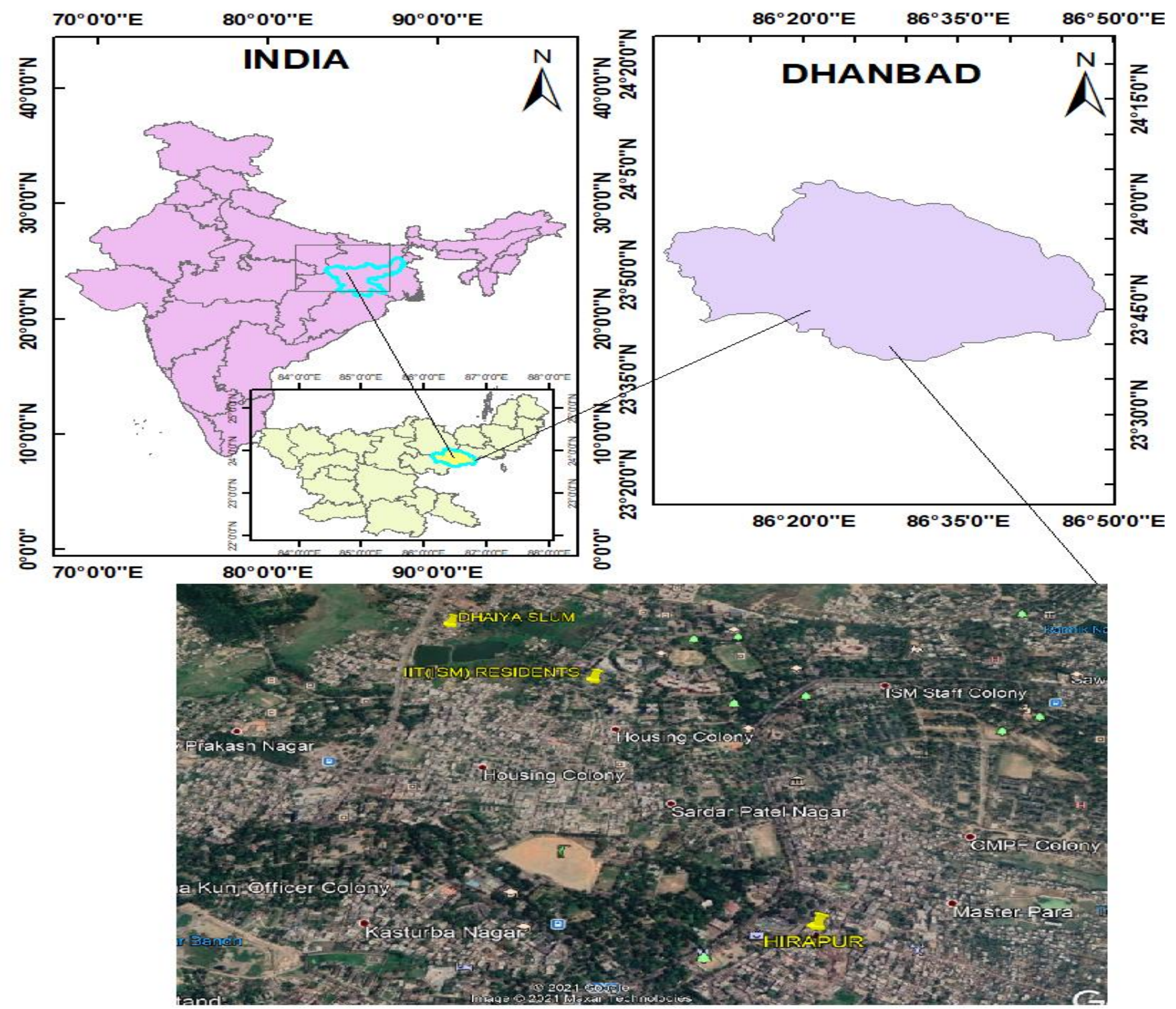

Fig 1: Study Area

\subsection{Study population and questionnaire}

154 A questionnaire survey was performed to screen and quantify the household and indoor areas 155 such as kitchen conditions, fuel used, cook-stove type, indoor conditions (ventilation, etc.).

156 After a peer literature review and applicability in the study area, the questions were developed 157 in the questionnaire (Bird 2009). For socioeconomic status (SES), we used the modified BG 158 Prasad scale and Kuppuswamy scale in our questionnaire (Bird 2009). The questions asked in 159 the survey appertain to general overview on fundamental attributes (Physical characteristics 160 (age, height, weight) and educational qualification), respiratory health status (cold, cough, 161 headache, chest tightness and breathlessness), number of family members, house structures and residing time in indoor conditions in different locations inside the house (Prabhu et al. 2019b). 
The data collected from women by direct interview and question-answer session. We provided our vacant questionnaire and asked them to fill and return the same. "How many family members are there in the house?" "What kind of fuel do you often use for cooking means?" "How many times spend in the house?" "Do you involve in any light activities during the residing hour?" We finally choose those women for our observation who gives satisfactory replies in 'Yes,' and they were considered under our scrutiny. Several parameters including ambient temperature, outdoor and indoor PM concentrations, socioeconomic status, primary cooking fuel use (Coal, Liquefied petroleum gas (LPG), Electricity), household conditions, kitchen structure, and its area, ventilation, smoking conditions in the house were considered for the study of exposure assessment. Woman's age, education, occupation, and their various activity inside the house are also considered.

Initially, we choose 67 households from the study area for our monitoring purposes. Out of this, 4 does not support and permit monitoring. So finally, we had 63 residences in our count. Out of 63 households, 32 are from the slum area comprising 1 or 2 room houses/ hut type structure. 13 were apartments, and the remainder were detached houses, usually 1 or 2 storey buildings. There was no external ventilation/exhaust system in slum areas and detached houses. Window and door provide natural ventilation to them. Apartments have an air-conditioning system in it. Coal is used in a handmade cook stove in the slum area for cooking purposes. LPG cylinders and some electric cook-stoves are used for cooking purposes in the apartment.

Various activities by people residing in the home also increase the indoor pollutants there (Ferro et al. 2004; Wu et al. 2007; Segalin et al. 2017; Adesina et al. 2020). In the various household, there is no proper ventilation and windows. In the slum area, there is no separate kitchen inside the household. Women from the study area spend more time than the other age groups inside a residence, so they are more susceptible to indoor exposure and health risk. We choose 125 women ages 19-65 years old (mean: $32 \pm 4$ years) from the study area of concerned 63 household. Out of 125 women, 68 were from slum areas, 28 middle-class family and the rest from the upper class in socioeconomic status with some refusal $(\mathrm{N}=7)$.

\subsection{Instrumentation}

An optical portable Aerosol Spectrometer (Grimm 1.109) was used for indoor particulate count and mass. For continuous monitoring of particulate matter concentration during the sampling period, we used it at a constant flow rate $(1.2 \mathrm{~L} / \mathrm{min})$ with a controller's help. 31 channel sizes range from 0.25 to $32 \mu \mathrm{m}$ particle size is measured by the Grimm with the certification issued 
by NIST (National Institute of Standards and Technology). The dual technology principle is used in the portable aerosol meter Grimm, i.e., the principle of light scattering for continuous and real-time measurements and the collection of total particles by the size of the PTFE filters 47mm (Burkart et al. 2010; Gupta and Elumalai 2017). Grimm was routinely calibrated with an accuracy of \pm 2 percent to ensure the precision of the collected data. All the required background measurements and flow checks were performed for the instrument before each monitoring. Q-Trak IAQ monitor (TSI model 7575x) was used for meteorological parameters like temperature and relative humidity measurement. With the help of an anemometer (Kestrel model 4500, Portable type), the wind speed was monitored.

\subsection{Data collection method}

Two-season monitoring was done in the study area. From 8 April 2019 to 12 July 2019 (95 days) for the summer season and between 30 November 2019 to 26 February 2020 (89 days) for the winter season in different sampling locations of the study area. Different continuous measurements were measured in every household in various places like the kitchen or where cooking took place (In case of no separate kitchen), nearest room to the cooking location, and restroom/bedroom. Instruments were mounted at the standard human breathing zone $(1.5 \mathrm{~m}$ from the ground) and $1.5 \mathrm{~m}$ away from the open doors/windows, where there was less chance of damage to the instrument. Micro meteorological parameters such as temperature, relative humidity, and wind speed were listed in the study area during the monitoring season (Table S1). We used data collected for the meteorological parameter from an installed automation weather station on the campus of IIT(ISM) Dhanbad for the reference site. Along with PM monitoring, Respiratory health symptoms of women in the study area were assessed with the help of a questionnaire.

\subsection{Assessment of the respiratory dust depositions (RDD)}

The RDD values for women residing in households were calculated for different day-to-day activities, including sitting/resting and basic household chores with light exercise. The values were calculated using equations given by the International Commission on Radiological Protection (ICRP 1994). The ICRP equations were previously used in many studies(Azarmi and Kumar 2016; Gupta and Elumalai 2017; Segalin et al. 2017; Sharma and Balasubramanian 2018).

$$
\mathrm{RDD}=(\mathrm{VT} \times \mathrm{f}) \times \mathrm{DF} i \times \mathrm{PM} i
$$


226 VT represents the tidal volume $\left(\mathrm{m}^{3}\right.$ per breath), $\mathrm{f}$ for the breathing frequency (breath per 227 minute), DFi denotes deposition fraction of a size fraction $\mathrm{i}$, and PMi was the mass concentration of different PM sizes.

229 The deposition fraction for the head airways region ( $\mathrm{DFHD}$ ) is

$\mathrm{DF}=\mathrm{IF} \times\left[\left(\frac{1}{1+\exp (6.84+1.183 * \ln (\mathrm{dp}))}\right)+\left(\frac{1}{1+\exp (0.924-1.885 * \ln (\mathrm{dp}))}\right)\right]$

231 Where $\mathrm{d}_{\mathrm{p}}$ is particle size in $\mu \mathrm{m}$ and IF is the inhalable fraction.

232 From the ICRP model, IF is given by

233

$I F=1-\left[0.5 *\left(1-\left(\frac{1}{1+0.00076 *(\mathrm{dp})^{2.8}}\right)\right)\right]$

The value of deposition fraction for the tracheobronchial region (DFTB) is

$D F=\left(\frac{0.00352}{d p}\right) \times\left[\exp \left(-0.234 *(\ln (d p)+3.40)^{2}\right)+(63.9 *(\exp (-0.891 *\right.$

The deposition fraction for the alveolar region $\left(\mathrm{DF}_{\mathrm{AL}}\right)$ is calculated by

$D F=\left(\frac{0.0587}{d p}\right) \times\left[\exp \left(-0.416 *(\ln (d p)+2.84)^{2}\right)+(19.11 *\right.$

240

241

242

243

The total deposition was computed by adding the values of all the regional depositions. The VT and f values were influenced by several factors like the gender of the person and the type of activity being done. For different positions like light exercise and sitting position for females, the VT values were considered $9.9 \times 10^{-4} \mathrm{~m}^{3}$ per breath and $4.6 \times 10^{-4} \mathrm{~m}^{3}$ per breath, respectively. For females, f values for the above-mentioned two positions were taken as 21 and 14 breaths per minute, respectively (Hinds).

\subsection{Exposure assessment}

Various types of activities inside the household by the women on a regular basis, with their different time spent, were recorded over 24 hours. Particulate concentrations in a different microenvironment like kitchen, room near the kitchen, living room, etc., associated with time spent pattern, by women were considered for developing the Exposure index. The Exposure index for women based on their time activity was developed as below. 
$253 E i=\sum_{i}^{I} \frac{C i * t k i}{C g * t a}$

254 Where

255 Ei: Exposure index

256 Ci: Different PM Concentration in particular microenvironment k.

257 tki: Aggregate time that individual "k" spends in microenvironment I.

258 I: Different micro-environments where for a specified time, individual "k" resides.

259 Cg: PM WHO guideline value $\left(25 \& 50 \mu \mathrm{g} / \mathrm{m}^{3}\right.$ for $\mathrm{PM}_{2.5} \& \mathrm{PM}_{10}$ respectively).

260 ta: Aggregate time $(24 \mathrm{~h})$.

\section{2.6.1. Development of Exposure index}

262 Exceeding pollutants dose above permissible limits is a significant source of adverse health

263 effects. For the potential health effects of female residents due to indoor particulate, we use the 264 Health Risk Assessment (HRA) approach. This methodology deals with a two-step measurement analysis. First, to assess the particles' toxicity in their exposure process (i.e., inhalation, absorption, and dermal contact) and then measure the particles' exposure level in the receptor. The toxicants, which are non-carcinogenic, give no significant exposure to exposure ranging from zero to acceptable intake daily/reference level. When these average dosage thresholds exceed the reference dose, the receptor is known to be at high risk to health (Chao and Wong 2002; Dolk et al. 2010; Sánchez-soberón et al. 2015; Sidhu et al. 2017). 2.6.2 Intake concentration (IC)

Exposure can occur by different pathways like ingestion, inhalation, or dermal absorption in the receptor (Kurt-Karakus 2012; Avila-Tang et al. 2013; Chen et al. 2016; Kumar and Goel 2016b). The inhalation of particles can originate various respiratory diseases with chronic health risks. International Agency for Research on Cancer (IARC 2013) declares PM as carcinogenic to individuals (Loomis et al. 2014). Here we mainly focus on the women in the study area, which indulge in the cooking process. Women's exposure to fine particles ( $\left.\mathrm{PM}_{2.5}\right)$ was determined in previous studies by considering the inhalation tract (Guo et al. 2004; Liao et al. 2019). Exposure duration and frequency with activity patterns were significantly impacted on exposure. The average hour for cooking was evaluated from the total daily time 
pattern. The exposure duration selected 20 years, as women spending more than 15 years cooking are at higher risk of COPD and other respiratory diseases (Alim et al. 2014; Hystad et al. 2015). The USEPA method is used to assess the potential intake concentration of $\mathrm{PM}_{10} \&$ $\mathrm{PM}_{2.5}$ (Morris et al. 2012; Bluyssen et al. 2016; Human 2019). With the assistance of an updated methodology, Intake concentration was determined utilizing the modified Eq. (2) (Forum 2019; Human 2019).

The chronic Intake concentration has been determined using the following calculation (USEPA, 2009).

$$
\boldsymbol{I C}=\frac{(\mathrm{CA} \times \mathrm{ET} \times \mathrm{EF} \times \mathrm{ED})}{A T}
$$

290

Where:

291

IC $\left(\mu \mathrm{g} / \mathrm{m}^{3}\right)=$ Intake concentration (defined as time weighted average concentration dependent on the exposure pattern);

$293 \mathrm{CA}\left(\mu \mathrm{g} / \mathrm{m}^{3}\right)=\mathrm{PM}$ concentration.

294 ET $=$ Exposure time (the period over which a person is supposed to be exposed during a normal day) that was $3.5 \mathrm{~h} /$ day for coal users and $4.5 \mathrm{~h} /$ day for clean fuel users, in our study. $\mathrm{EF}($ days/year) $=$ Exposure frequency (defined as the amount of exposure events over an exposure duration) taken as 350 days/year.

$\mathrm{ED}($ years $)=$ Exposure duration (the period during which a person is exposed to lifetime), taken as 20 years for female residents. $\mathrm{AT}=$ Averaging time (period over which exposure is averaged) that equals to ED in years $\times 365$ days/year×24 h/day for non-carcinogens.

All of the default mentioned above values have been added, considering the residential criteria specified in USEPA (2014) and used in Indian study (Sidhu et al. 2017; Deepthi et al. 2019).

\subsubsection{Toxicological risk}

305

Hazard Quotient is used as an indicator of toxicological risk. As per the hazard quotient method recommended by USEPA, 2005 Eq. 3, it is characterized as the proportion between consumption fixation (Intake concentration) and the reference dose (Reference concentration). Here reference concentration for $\mathrm{PM}_{10} \& \mathrm{PM}_{2.5}$ was taken the same as the WHO guideline (50 \& $25 \mu \mathrm{g} / \mathrm{m}^{3}$ ). As neither WHO nor NAAQS provides a standard value for $\mathrm{PM}_{1}$ in Ambient/Indoor Air quality, the value of finer particles $\left(\mathrm{PM}_{1}\right)$ cannot be compared with any given standards. HQ values less than 1 do not impact significant effects on human health. More than $1 \mathrm{HQ}$ value might raise concern for the potential risk of human health. 
$314 \quad H Q=\frac{I C}{R f C}$ Where,

315 IC: Intake concentration $\left(\mathrm{PM}_{10} \& \mathrm{PM}_{2.5}, \mu \mathrm{g} / \mathrm{m}^{3}\right)$

316 RfC: Reference concentration $\left(\mathrm{PM}_{10} \& \mathrm{PM}_{2.5}, \mu \mathrm{g} / \mathrm{m}^{3}\right)$

$317 \quad 2.7$ Statistical analysis

318 All the statistical analyses were performed using the SPSS 26.0 tools, Origin 2019b and 319 Microsoft Excel 2013. Physical characteristics (age, height, weight, BMI) among women in 320 the household were compared by student t-test using mean values. A Chi-square test assesses 321 the significance of respiratory symptoms. Descriptive statistics were initially investigated for 322 continuous PM data and other micro-environmental parameters. In comparison, skewness was 323 used to determine the data distribution is symmetrical or asymmetrical. Variation of seasonal 324 particulate matter and ratios indoor/outdoor were also measured, consistent with 325 meteorological parameters. The Pearson correlation coefficient compared the degree of indoor326 outdoor PM at the monitoring sites. The Mann-Whitney $U$ test has been used to compare two 327 non-parametric and independent samples (for example, such as a pollutant concentration in two 328 separate fuel types). This test compares with the median in order to assess that there are two 329 samples from the same population. The tests for $\mathrm{p}<0.05$ were considered as significant. The 330 linear regression analysis was used to predict the trend analysis of RDDs under various 331 household conditions. It compares the values of the RDDs as dependent variables in different 332 regions $\mathrm{HD}, \mathrm{TB}$, and $\mathrm{AL}$ and different $\mathrm{PM}$ fractions $\left(\mathrm{PM}_{10}, \mathrm{PM}_{2.5} \& \mathrm{PM}_{1}\right)$ as independent 333 variables.

\section{3. Result and discussion}

\subsection{Questionnaire Survey}

336 Our investigation's primary objectives were to epitomize the indoor air conditions and their exposures for the women, assess the relationship between PM and RDDs, and thus recognize various factors connected with women's exposure to PM like individual behaviour, household conditions, and indoor micro environmental factors.

340 In IIT(ISM) area, the average participant was found with higher education. In the slum area, 341 mostly completed primary school (81\%), and the rest had completed secondary school (19\%). Most women (90\%) were housewives, although a few engaged in domestic work (7\%) in other 343 houses for livelihood. Out of 63 households in the study area, for the vital source of energy, 
traditional fuels (coal) were used in 33 houses (52\%), kerosene used in 8 houses (13\%), and the remaining 22 houses (35\%) used LPG and electricity (clean fuels). Based on our

346 Questionnaire survey, the result found in the study area is summarised in Table 1. Significant

347 differences were found in the physical characteristics of the women in the study area $(\mathrm{p}<0.01)$

348 (Table 1).

349 Table 1: Outcomes of Questionnaire Survey

\begin{tabular}{|c|c|c|c|}
\hline Characteristic & $\begin{array}{l}\text { Dhaiya } \\
\text { Slum }\end{array}$ & Hirapur & IIT(ISM) \\
\hline Number of women to response $(\mathrm{N})$ & 68 & 28 & 22 \\
\hline Number of meals made per day (n) & $2 \pm 1$ & $3 \pm 1$ & $3 \pm 1$ \\
\hline Fuel use & $\begin{array}{l}\text { Coal, } \\
\text { Biomass }\end{array}$ & LPG & $\begin{array}{l}\text { LPG, } \\
\text { Electricity }\end{array}$ \\
\hline Cooking duration (hr) & $3 \pm 0.5$ & $5 \pm 0.5$ & $4 \pm 0.5$ \\
\hline \multicolumn{4}{|l|}{ Residing duration in different locations: } \\
\hline Living room (hr.) & $12 \pm 0.5$ & $12 \pm 0.5$ & $9 \pm 0.5$ \\
\hline Kitchen (hr.) & $3 \pm 0.5$ & $5 \pm 0.5$ & $4 \pm 0.5$ \\
\hline Outdoor within the home (hr.) & $5 \pm 0.5$ & $4 \pm 0.5$ & $6 \pm 0.5$ \\
\hline Away from home (hr.) & $4 \pm 0.5$ & $3 \pm 0.5$ & $5 \pm 0.5$ \\
\hline Family size (n) & $5 \pm 2$ & $7 \pm 1$ & $5 \pm 2$ \\
\hline Total Residing time in that house (years) & $13 \pm 3$ & $12 \pm 5$ & $9 \pm 5$ \\
\hline $\begin{array}{l}\text { Age }(\mathrm{yr})(\text { mean }) \\
(\min -\max )\end{array}$ & $\begin{array}{l}27 \pm 5^{\mathrm{a}} \\
(19-65)\end{array}$ & $\begin{array}{l}32 \pm 6 \\
(23-63)\end{array}$ & $\begin{array}{l}33 \pm 5 \\
(25-60)\end{array}$ \\
\hline Height $(\mathrm{cm})$ & $150 \pm 5.8$ & $155 \pm 6.2$ & $156 \pm 8.4$ \\
\hline Weight (kg) & $40 \pm 15$ & $45 \pm 15$ & $45 \pm 15$ \\
\hline Body mass index $\left(\mathrm{kg} / \mathrm{m}^{2}\right)$ & $22.6 \pm 2.7$ & $22.9 \pm 2.6^{\mathrm{a}}$ & $23.6 \pm 2.3$ \\
\hline Smoking history (\%) & 1.1 & 0.1 & 0.6 \\
\hline
\end{tabular}




\begin{tabular}{|l|l|l|l|}
\hline Respiratory health status (number out of total N)* & & & \\
No symptoms (\%) & $06(8.82)$ & $10(35.71)$ & $11(50)$ \\
Breathless $(\%)$ & $04(5.88)$ & $03(10.71)$ & $02(9.09)$ \\
Cold (\%) & $12(17.65)$ & $04(14.29)$ & $03(13.64)$ \\
Cough (\%) & $13(19.11)$ & $02(7.14)$ & $02(9.09)$ \\
Cold \& cough (\%) & $11(16.17)$ & $02(7.14)$ & $01(4.55)$ \\
Headache $(\%)$ & $10(14.70)$ & $03(10.71)$ & $01(4.55)$ \\
Chest tightness $(\%)$ & $07(10.29)$ & $03(10.71)$ & $01(4.55)$ \\
Tired/strained eyes $(\%)$ & $05(7.35)$ & $01(3.57)$ & $01(4.55)$ \\
\hline Ventilation & None & Some & Adequate \\
\hline
\end{tabular}

$350 \quad{ }^{\mathrm{a}} \mathrm{p}<0.05, *$ Nonsignificant difference

\section{$351 \quad 3.2$ Time activity pattern of Women indoor}

352 PM concentration varies significantly, according to multiple activities in an indoor 353 environment. As per the daily time spent and activities of women recorded in the study area, it

354 was found that women spent between 4-5 hours per day for cooking purposes based on various 355 locations $(\mathrm{p}<0.01)($ Fig 2$)$.
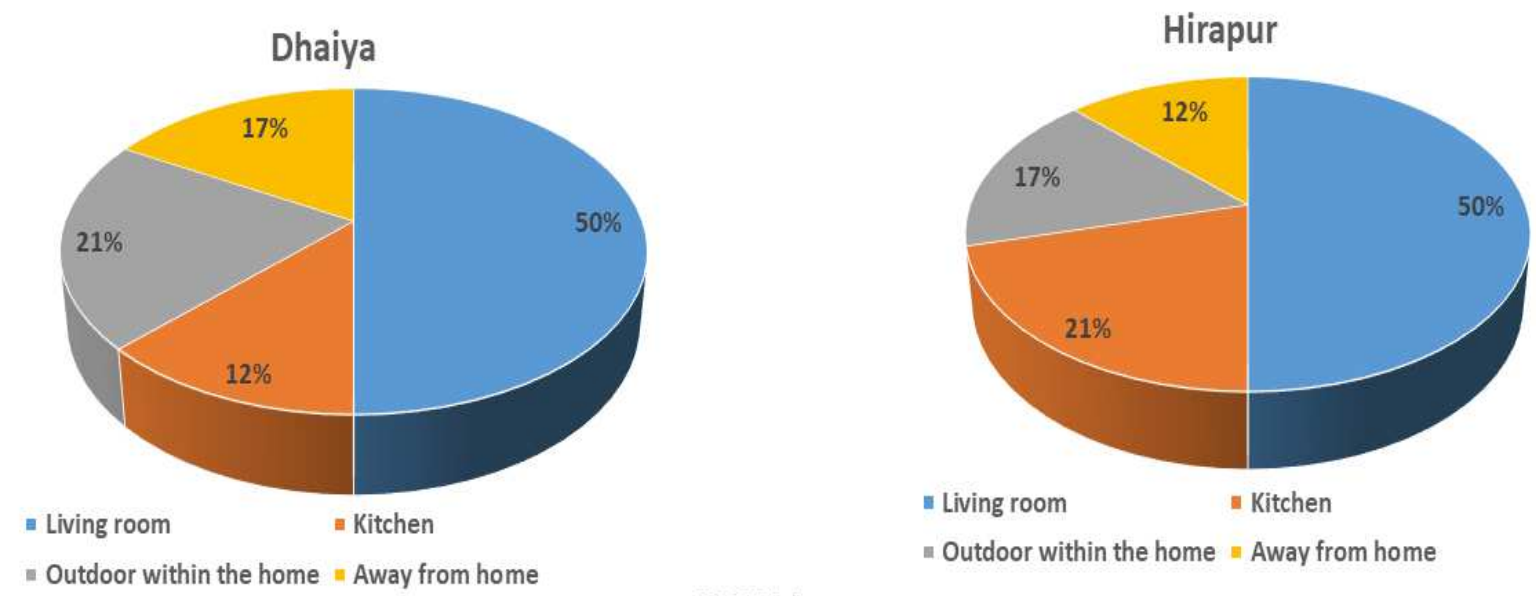

IIT ISM

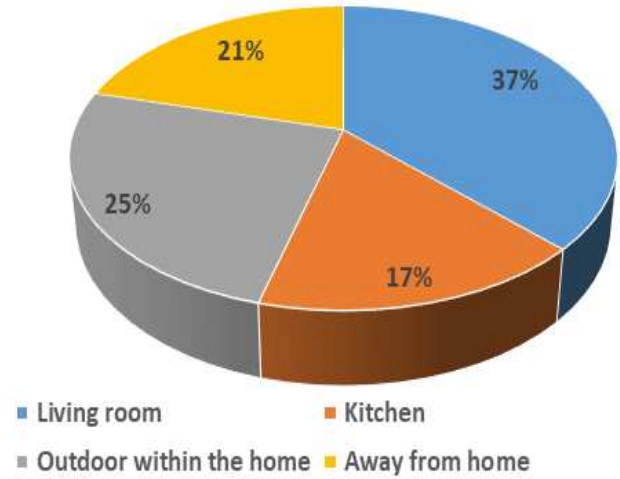




\section{Fig 2: Time activity pattern in different locations}

\subsection{Size segregated PM}

\section{$359 \quad$ 3.3.1 Temporal variation of PM concentration}

360 The difference in PM concentrations during cooking and other than cooking periods is significantly high, which depicts that cooking is a significant source of PM concentrations in the study area's household. Data collected for PM shows, morning time in both the winter and summer periods gives significantly higher PM concentrations than the evening period $(\mathrm{p}<0.01)$ (Fig $3 \mathrm{a}, \mathrm{b}$ ). The majority of households used to prepare breakfast and lunch together. So morning cooking time is more in the study area because the number of items cooked in the morning period is more than the evening period, which causes higher exposure to women. PM concentration in the early morning, when human activities start, shows lower value. A gradual increase in PM vales was observed with the onset of household activities like cooking, the peaks being between 9-10 am. A decrease in PM concentration between the noon and evening was noted in all the locations, majorly in IIT(ISM) area. The other areas were affected by outdoor vehicular pollution at the selected time range. At night, indoor PM concentration

372 increases with the cooking period (6-9 pm), and then downturn observes as less outdoor vehicular pollution occurs after $9 \mathrm{pm}$ in the nearby area. The cooking times influenced the indoor air PM concentrations, as seen in Fig. 3 (a, b). During cooking times, PM2.5 and PM10 levels reached up to $800 \mathrm{~g} / \mathrm{m}^{3}$ and $1000 \mathrm{~g} / \mathrm{m}^{3}$, respectively, although they were below $60 \mathrm{~g} / \mathrm{m}^{3}$ and $100 \mathrm{~g} / \mathrm{m}^{3}$ during non-cooking hours in winter. Almost the same trend follows in summer.

377 Seasonal changes in temporal variation are not highly significant inside the household 378 ( $\mathrm{p}<0.05)$. The same pattern was observed in (Sharma and Jain 2019) as indoor PM varies from morning to noon. 

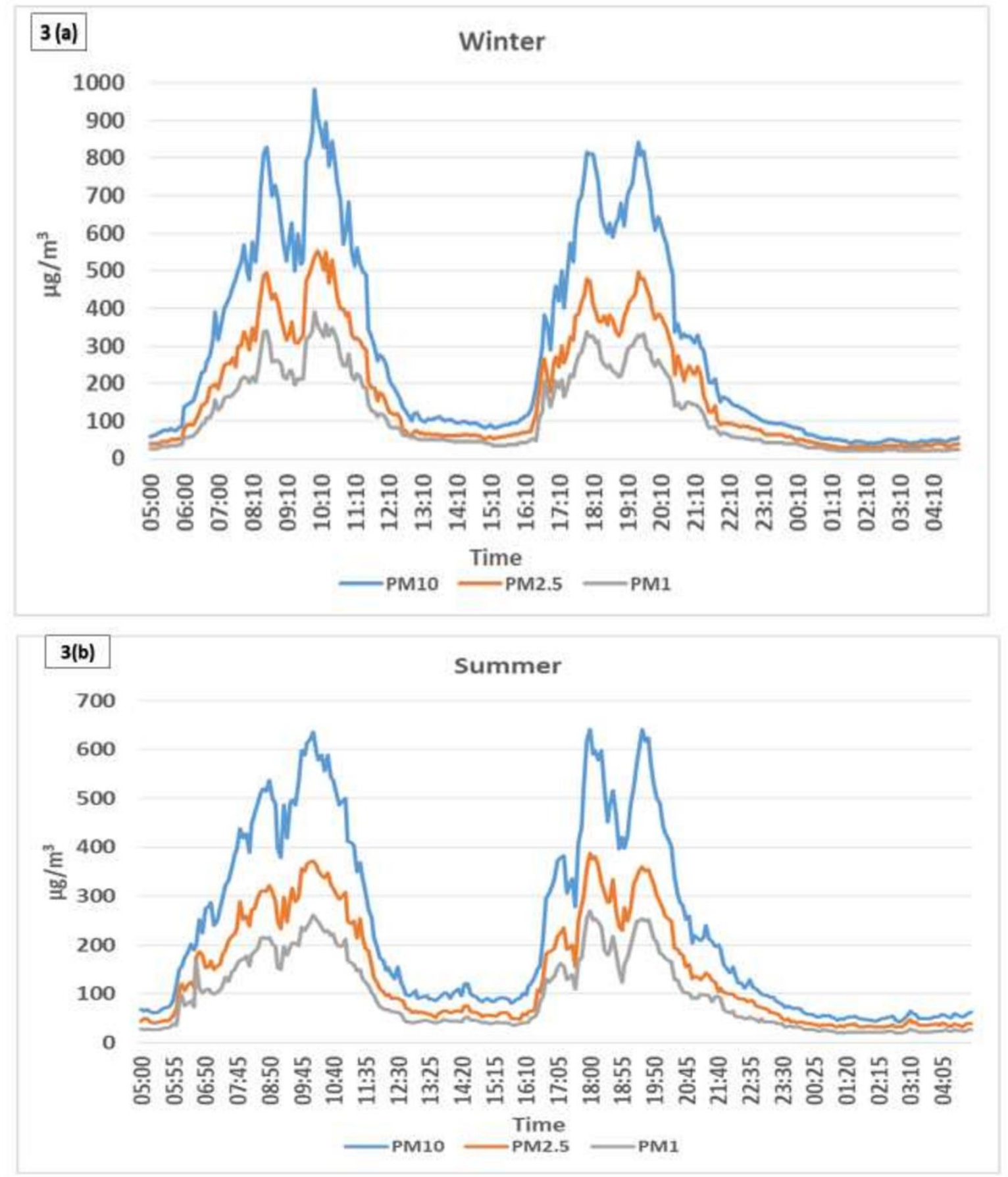

381 Fig 3 (a): PM variation during Winter time 


\subsubsection{PM fractions}

From Fig 4, it is clear that the distribution of PM in the household of the study area is asymmetric, with a more significant variability according to indoor conditions. Seasonal variability in PM concentration is found significant in $p$ test $(p<0.01)$, with the significantly highest amid winter and the lowest in the summer. Results show the seasonal variation of $24 \mathrm{~h}$ average PM concentration for the different size ranges, the highest concentration was observed in December month with the mean values of $\mathrm{PM}_{10}, \mathrm{PM}_{2.5}$ and $\mathrm{PM}_{1}$ was $185.12 \mu \mathrm{g} / \mathrm{m}^{3}$ (95\% CI: 153.84, 216.43), $115.31 \mu \mathrm{g} / \mathrm{m}^{3}$ (95\% CI: 86.68, 143.92) \& 74.68 $\mu \mathrm{g} / \mathrm{m}^{3}$ (95\% CI: 55.05,94.31) respectively than the June month found lowest with the values of $137.28 \mu \mathrm{g} / \mathrm{m}^{3}(95 \% \mathrm{CI}$ :

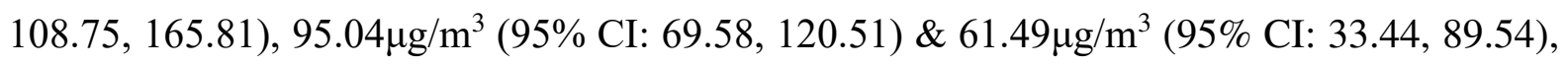
respectively (Fig 4). The highest value in the winter season is correlated with fuel combustion, burning of solid biomass for heating purposes, and unfavorable weather conditions for emission dispersion (stagnant weather and inversion of temperature). Along with primary emission accumulation, new particulate formation and subsequent development could further intensify the abundance of fine PM (Tian et al. 2017).

PM concentrations identified in Dhaiya Basti (slum area), were higher than those in Hirapur and IIT(ISM) residential area. In household primarily cooking with electricity or LPG, mean $\mathrm{PM}_{10}, \mathrm{PM}_{2.5} \& \mathrm{PM}_{1}$ concentrations were $87.74 \mu \mathrm{g} / \mathrm{m}^{3}$ (95\% CI: 65.75, 109.73), $66.07 \mu \mathrm{g} / \mathrm{m}^{3}$ (95\% CI: $45.83,86.31), \& 34.29 \mu \mathrm{g} / \mathrm{m}^{3}$ (95\% CI: 14.62, 53.96), compared with $214.77 \mu \mathrm{g} / \mathrm{m}^{3}$ (95\% CI: 172.19, 257.36), 132.09 $\mu \mathrm{g} / \mathrm{m}^{3}$ (95\% CI: 98.98, 165.18), \& $83.81 \mu \mathrm{g} / \mathrm{m}^{3}$ (95\% CI: $61.14,106.48)$, respectively in household cooking with coal. In winter, PM concentrations were increases in household with no electrical heater, where people use coal based stoves for room heating purpose also with mean $\mathrm{PM}_{10}, \mathrm{PM}_{2.5} \& \mathrm{PM}_{1}$ were $226.37 \mu \mathrm{g} / \mathrm{m}^{3}$ (95\% CI: 165.58, 287.15), $150.19 \mu \mathrm{g} / \mathrm{m}^{3}$ (95\% CI: 110.33, 190.06), \& $87.17 \mu \mathrm{g} / \mathrm{m}^{3}$ (95\% CI: 57.88, 116.46), respectively compared with household cooking with LPG only $\left(111.17 \mu \mathrm{g} / \mathrm{m}^{3}\right.$, (95\% CI: 52.87 ,

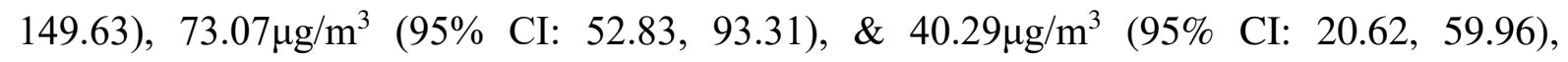
respectively).

Two-way ANOVA test reveals a statistically significant difference in concentrations of $\mathrm{PM}_{1}$ between AC and Non-AC household $(\mathrm{p}<0.01)$ and coal and LPG used household $(\mathrm{p}<0.05)$. $\mathrm{PM}_{10}$ and $\mathrm{PM}_{2.5}$ observe a similar trend $(\mathrm{p}<0.05)$ with the coal and LPG used household. Inside household variability in both seasons for $\mathrm{PM}_{10}$ and $\mathrm{PM}_{2.5}(0.19-0.57$ \& $0.23-61$ in summer; 


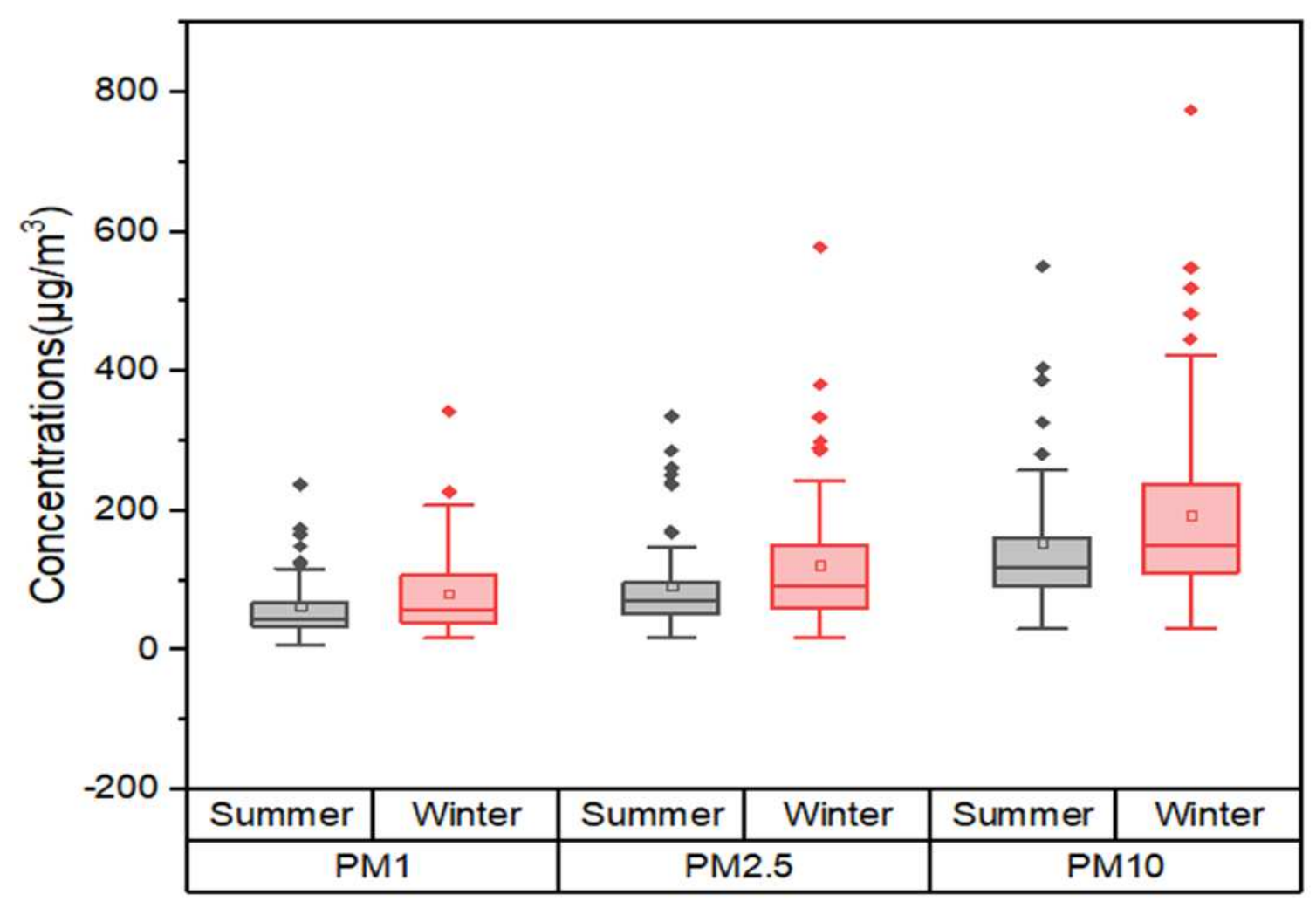

416

$417 \quad$ Fig 4: Seasonal variation in PM concentration

\subsubsection{PM Size Distribution}

This ratio is significant because the time of residence of fine PM is longer than several days, which raises the risk of lung disease (Paulin and Hansel 2016). During the entire sampling period, the PM fractions show a normal fluctuation with the mean ratios of different particle sizes $\mathrm{PM}_{2.5} / \mathrm{PM}_{10}, \mathrm{PM}_{1} / \mathrm{PM}_{10}, \mathrm{PM}_{1} / \mathrm{PM}_{2.5}$, which is equal to $0.738,0.487$, and 0.524 , respectively. Concentrations of indoor $\mathrm{PM}_{10}$ and $\mathrm{PM}_{2.5}$ were moderately correlated $(\mathrm{r}=0.73$, 95\% CI: 0.60, 0.84) with a stronger summer correlation ( $\mathrm{r}=0.92,95 \% \mathrm{CI}: 0.84,0.98)$ compared to winter ( $\mathrm{r}=0.6895 \% \mathrm{CI}$ : $0.46,0.84)$ respectively. Comparable values were reported in some previous studies. (de la Sota et al. 2018) found $\mathrm{PM}_{2.5} / \mathrm{PM}_{10}$ value equal to 0.625 on average,

427 while this ratio varied from 0.40 to 0.64 in Bangladesh (Begum et al. 2009).

The ratio $\mathrm{PM}_{2.5} / \mathrm{PM}_{10}$ has lower values in the household using $\mathrm{LPG}$, indicating lower $\mathrm{PM}_{2.5}$ mass emissions as compared to coal user. High ratios in Dhaiya slums show the more presence of finer particles inside homes. Coal uses for cooking inside the house, and vehicular pollution 
431

432

433

434

435

436

437

438

439

440

441

442

443

444

445

446

by attached roads influences the abundance of fine particles loading in those households. $\mathrm{PM}_{2.5} / \mathrm{PM}_{10}$ ratio was found higher during cooking periods in all households with an average of 0.85 . Low $\mathrm{PM}_{2.5} / \mathrm{PM}_{10}$ ratios ( 0.41 on average) were measured during non-cooking periods. This may be due to various factors such as resuspension of indoor-outdoor dust, residents' activities, household structures like closed and open kitchens, etc. This emphasizes the importance of fine particles in household during cooking times and their coarser nature during non-cooking periods. Different ventilation rates, kitchen structure, and the interval between cooking periods may be the reason for the differences in the $\mathrm{PM}_{2.5} / \mathrm{PM}_{10}$ ratio value.

\subsubsection{Ind-out interaction}

As slum areas are closer to the road network, heavy traffic generates high loading PM, which directly enters the residence. Weather conditions, tightness of buildings, indoor accessories like air conditioners, exhaust fans, windows, doors, etc., also affect the ind-out air exchange (Chao and Wong 2002). Mean outdoor $24 \mathrm{~h}$ average $\mathrm{PM}_{10}, \mathrm{PM}_{2.5} \& \mathrm{PM}_{1}$ concentrations in study area tabulated in Table 2 based on seasonal variation. The seasonal variation of outdoor air quality between winter and summer was more than the month-to-month variation.

Table 2: Ind-out interaction in different locations

\begin{tabular}{|l|l|l|}
\hline $\begin{array}{c}\text { Monitoring } \\
\text { period }\end{array}$ & \multicolumn{1}{|c|}{ Winter } & \multicolumn{1}{c|}{ Summer } \\
\hline Dhaiya & $143.21 \mu \mathrm{g} / \mathrm{m}^{3}(95 \%$ CI: $112.63,173.48)$ & $123.42 \mu \mathrm{g} / \mathrm{m}^{3}(95 \%$ CI: $94.79,151.79)$ \\
\hline PM $_{10}$ & $112.87 \mu \mathrm{g} / \mathrm{m}^{3}(95 \%$ CI: $79.72,145.89)$ & $85.69 \mu \mathrm{g} / \mathrm{m}^{3}(95 \%$ CI: $65.63,108.63)$ \\
\hline PM $_{2.5}$ & $73.68 \mu \mathrm{g} / \mathrm{m}^{3}(95 \%$ CI: $41.32,106.14)$ & $57.93 \mu \mathrm{g} / \mathrm{m}^{3}(95 \%$ CI: $38.26,78.86)$ \\
\hline PM $_{1}$ & $129 . .37 \mu \mathrm{g} / \mathrm{m}^{3}(95 \%$ CI: $78.59,173.89)$ & $104.42 \mu \mathrm{g} / \mathrm{m}^{3}(95 \%$ CI: 61.43, 147.42) \\
\hline Hirapur & $103.79 \mu \mathrm{g} / \mathrm{m}^{3}(95 \%$ CI: $75.96,129.96)$ & $74.71 \mu \mathrm{g} / \mathrm{m}^{3}(95 \%$ CI: $35.97,113.17)$ \\
\hline PM$_{10}$ & $57.19 \mu \mathrm{g} / \mathrm{m}^{3}(95 \%$ CI: $39.56,74.53)$ & $48.17 \mathrm{~g} / \mathrm{m}^{3}(95 \%$ CI: $29.24,67.19)$ \\
\hline PM $_{2.5}$ & & \\
\hline PM 1 & $85.11 \mu \mathrm{g} / \mathrm{m}^{3}(95 \%$ CI: $63.11,106.89)$ & $64.23 \mu \mathrm{g} / \mathrm{m}^{3}(95 \%$ CI: $44.02,84.57)$ \\
\hline IITISM & & \\
\hline PM 10 & & \\
\hline
\end{tabular}




\begin{tabular}{|l|l|l|}
\hline PM $_{2.5}$ & $59.72 \mu \mathrm{g} / \mathrm{m}^{3}$ (95\% CI: 39.47, 79.95) & $48.97 \mu \mathrm{g} / \mathrm{m}^{3}$ (95\% CI: 29.15, 68.62) \\
\hline PM $_{1}$ & $38.94 \mu \mathrm{g} / \mathrm{m}^{3}$ (95\% CI: $\left.20.87,57.64\right)$ & $29.34 \mu \mathrm{g} / \mathrm{m}^{3}$ (95\% CI: 13.89, 46.79) \\
& & \\
\hline
\end{tabular}

447

448

The weighted mean concentrations of $\mathrm{PM}_{10}$ and $\mathrm{PM}_{2.5}$ outside the home indicate that outdoor air is the dominant source of indoor $\mathrm{PM}_{10}$ and $\mathrm{PM}_{2.5}$. As a result, infiltration/ventilation is a key factor in determining indoor $\mathrm{PM}_{10}$ concentrations in the household. Indoor sources such as cooking, smoking, biomass burning for heating, and incense burning lead to particulate matter production. Simultaneously, higher concentrations in monitoring locations can be due to road and soil particles re-suspension in the air. Wide variations in indoor and outdoor $\mathrm{PM}_{10}, \mathrm{PM}_{2.5}$, and $\mathrm{PM}_{1}$ were found with skewness of $0.18-0.29$ for $\mathrm{PM}_{10}, 0.23-0.55$ for $\mathrm{PM}_{2.5}$, and 0.07-0.95 for $\mathrm{PM}_{1}$. Through applying single-way Anova (SPSS 26.0) to mean particulate concentrations in all households in the Dhaiya slum, significant values $(\mathrm{p}=0.256)$ for $\mathrm{PM}_{10}, \mathrm{PM}_{2.5}$ and $\mathrm{PM}_{1}$ were found to be more than 0.05 . It implies no substantial variation between the PM concentrations of such houses and thus has common sources that lead to particulate pollutant production in their environment.

\subsection{Respiratory dust depositions (RDDs)}

\subsubsection{Respiratory dust depositions (RDDs) for Women}

Estimating RDDs values for size segregated PM illustrates PM's depositions in the various region of the respiratory tract (Sharma and Balasubramanian 2018). Generally, cooking done by the women has in a sitting and standing position. The woman does not carry out heavy exercises at indoor conditions, so we calculated the RDDs by considering two positions like seated position and light exercise for females. PM exposure of the indoor condition was analyzed for the RDDs in all three regions (HD, TB, and AL) for females inside house premises during seated position and light exercise. Particulate deposition in various airways depends mainly on variations in airways' geometric structure (Jaques and Kim 2000). Due to an increase in breathing frequency by light exercise, the accumulation of PM in the respiratory tract's airways increases and thus gives a higher RDD value than the sitting posture (Hinds).

In the given expressions for RDDs, we follow the assumption that all particles (100\%) infiltrate via nose or mouth to the respiratory tract. The total RDDs are the summation of the value observed in the entire three regions (HD, TB \& AL). Figure 4 provides an estimation of RDDs 
due to different particle sizes ( $\mathrm{PM}_{10}, \mathrm{PM}_{2.5}$ \& $\left.\mathrm{PM}_{1}\right)$ during two different positions, i.e., seated and light exercise conditions.

The RDDs observed in the HD region is $3.795 \mu \mathrm{gmin}^{-1}$ (SD: 2.781, 0.521-17.118) for $\mathrm{PM}_{10}$, $2.078 \mu \mathrm{gmin}^{-1}$ (SD: 1.625, 0.339-9.706) for $\mathrm{PM}_{2.5}$, and $0.603 \mu \mathrm{g} \mathrm{min}{ }^{-1}$ (SD: 0.462, 0.1012.446) for $\mathrm{PM}_{1}$ during light exercise. On the other hand, the observed RDDs value in HD region was $1.176 \mu \mathrm{gmin}^{-1}$ (SD: 0.862, 0.162-5.303) for PM10, $0.643 \mu \mathrm{gmin}^{-1}$ (SD: 0.503, 0.105-3.007) for $\mathrm{PM}_{2.5}$, and $0.187 \mu \mathrm{gmin}^{-1}$ (SD: 00143, 0.032-0.758) for $\mathrm{PM}_{1}$ during cooking and seated position. During different positions like Light exercise and the Sitting condition, values found

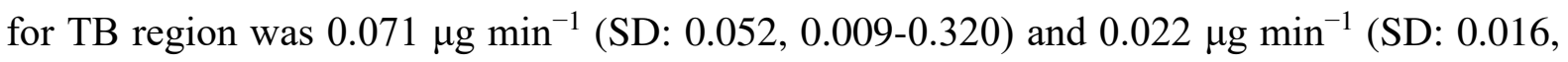

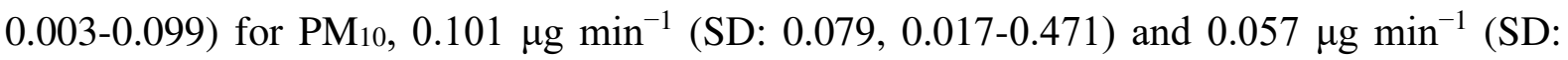
$0.044,0.009-0.265$ ) for $\mathrm{PM}_{2.5}, 0.079 \mu \mathrm{g} \mathrm{min}^{-1}$ (SD: 0.061, 0.013-0.323) and 0.017 $\mu \mathrm{g} \mathrm{min}$ (SD: $0.014,0.003-0.072$ ) respectively for $\mathrm{PM}_{1}$ to females. For different positions like Light exercise and the Sitting condition, values found for AL region was $0.091 \mu \mathrm{gmin}^{-1}$ (SD: 0.067, $0.012-0.408$ ) and $0.028 \mu \mathrm{gmin}^{-1}$ (SD: 0.021, 0.003-0.126) for $\mathrm{PM}_{10}, 0.325 \mu \mathrm{gmin}^{-1}$ (SD: 0.254, $0.053-1.521$ ) and $0.183 \mu \mathrm{gmin}^{-1}$ (SD: $0.143,0.031-0.857$ ) for $\mathrm{PM}_{2.5}, 0.257 \mu \mathrm{gmin}^{-1}$ (SD: 0.197, 0.043-1.04) and $0.057 \mu \mathrm{gmin}^{-1}$ (SD: 0.044, 0.009-0.233) respectively for $\mathrm{PM}_{1}$ to females. Of the three size fractions analyzed, the largest total RDD was observed for coarse particles ( $\mathrm{PM}_{2.5}$ 10), followed by fine particles ( $\mathrm{PM}_{1.0-2.5}$ and $\mathrm{PM}_{<1}$ ) (Fig 5). The RDDs observe in slum areas are quite high as compare to the IIT(ISM) area. Women residing in those areas are more prone to health risks than others part of the study area. Total respiratory tract deposition was estimated to be more in both fine and coarse particle ranges. Collectively, particle Deposition Fraction (DF) was also calculated in three respiratory tract regions, i.e. the head airways (DFHA), tracheobronchial (DFTB), and alveolar (DFAL). DF was highest in the head airways region for coarser particles and in the alveolar region for fine particles. (Jain 2017) also observed similar trends in a study for concentrations in vehicular particles in Delhi. For a study on a variety of kitchen and stove styles, the overall RDDs were high in the enclosed kitchen type household for the coarser and fine particle sizes (Sharma and Jain 2019). The final observed RDDs values confirm that for the woman, the AL region is the most prominent affected zone by the fine particles ( $\left.\mathrm{PM}_{2.5}\right)$ as compared to TB region in both positions in all study locations. 
Total RDD

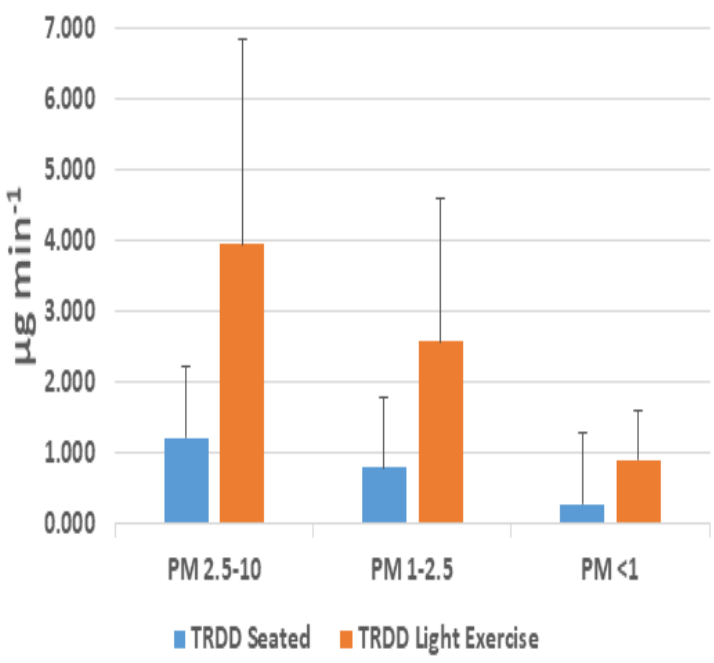

TB

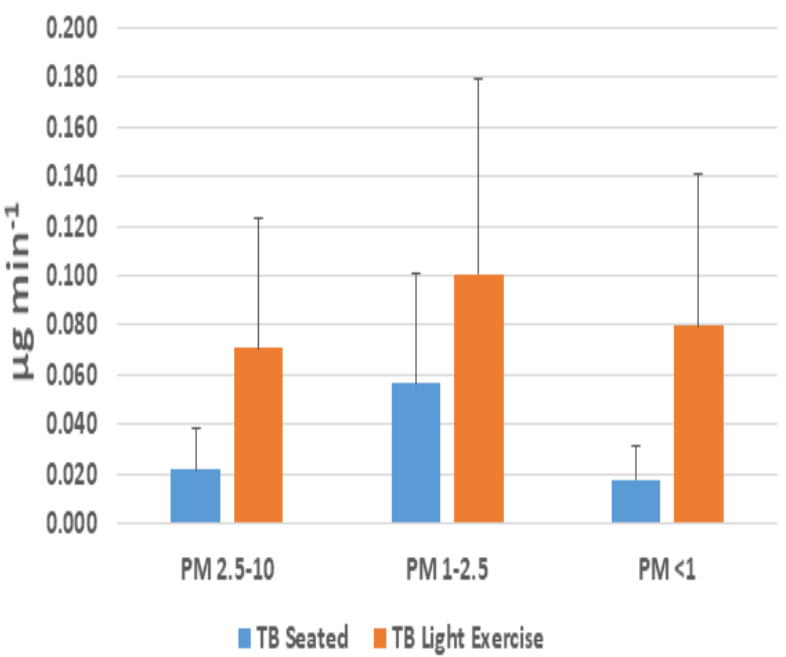

HD

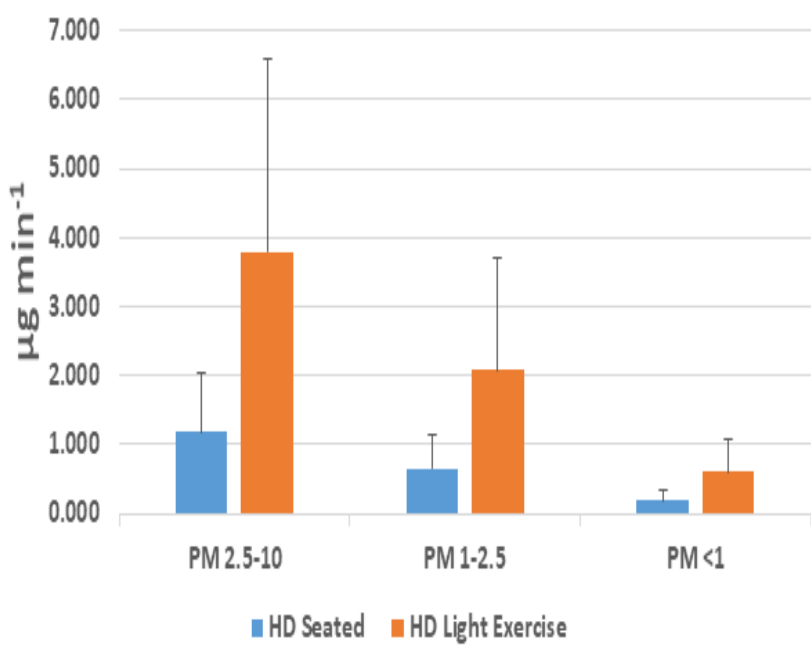

AL

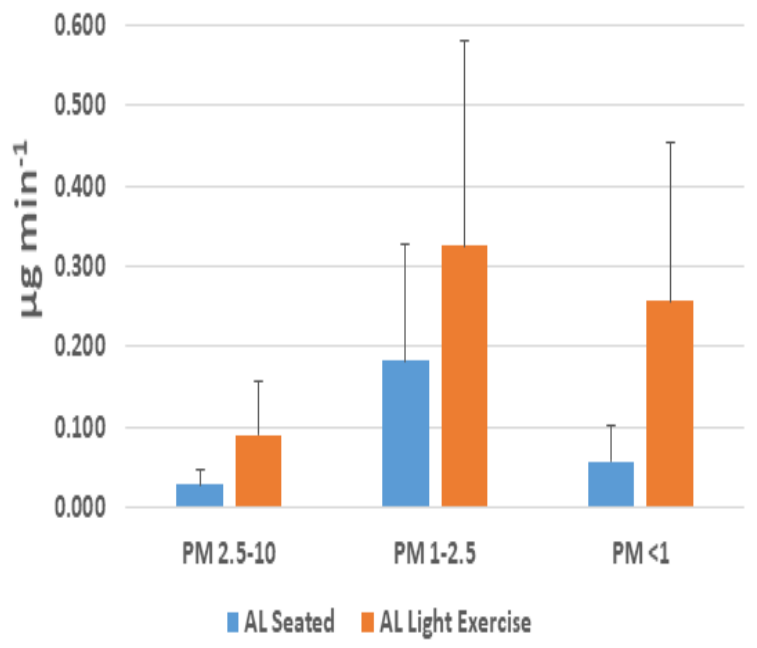

505

506 Fig 5: Rdds due to different Particles size during two different positions.

507 The HD values are followed the decreasing trend in $\mathrm{PM}_{10}$ (59\%), $\mathrm{PM}_{2.5}$ (32\%) and $\mathrm{PM}_{1}(09 \%)$

508 whereas the RDDs for AL region significantly increases as $\mathrm{PM}_{10}(11 \%), \mathrm{PM}_{2.5}(68 \%)$ and $\mathrm{PM}_{1}$

509 (21\%) (Fig 6). 
HD

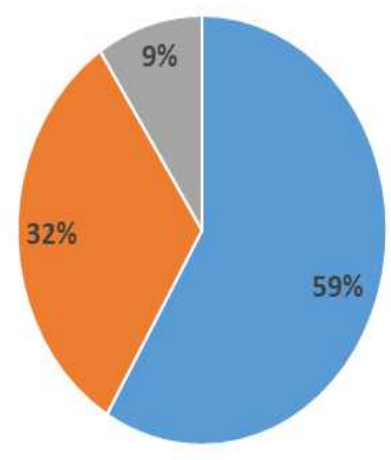

| $\mathrm{PM} 2.5-10$ | $\mathrm{PM} 1-2.5$ ॥PM
TB

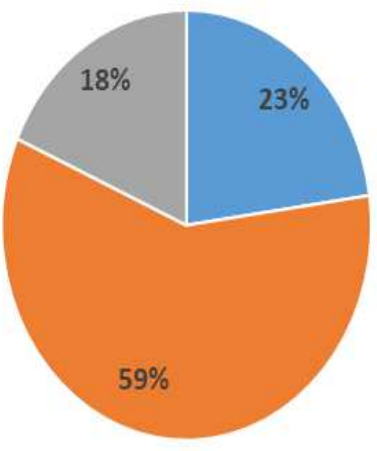

॥ $\mathrm{PM}$ 2.5-10 $\approx \mathrm{PM} 1-2.5 \approx \mathrm{PM}<1$
AL

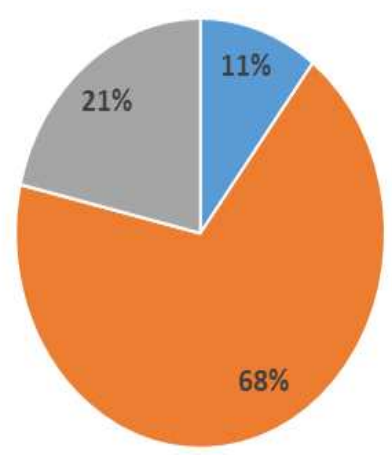

| $\mathrm{PM} 2.5-10$ | $\mathrm{PM} 1-2.5 \quad$ | $\mathrm{PM}<1$

511 Fig 6: Percentage variation of Rdds values for different Particles size (PM10, $\mathbf{P M}_{2.5}$, and

$\left.512 \mathbf{P M}_{1}\right)$ in different regions (HD, TB and $\left.\mathrm{AL}\right)$.

513 To find the effect of the fine particle, we compared the value of $\mathrm{PM}_{2.5-10}$ and the sum of the rest

514 two size groups $\left(\mathrm{PM}_{1-2.5} \& \mathrm{PM}_{<1}\right)$ (Fig 7). In the case of coarser particles, the amount of RDDs

515 during light exercise and sitting positions was slightly higher than the remaining fine particles,

516 up to $11.5 \%$. This finding is significant as these fine particles have an adverse impact on

517 receptor health relative to larger particles (Heal et al. 2012; Kesavachandran et al. 2015; Chen

518 et al. 2016), and these fine particles may help the deposition of endotoxin in the pulmonary

519 alveoli (Jena and Singh 2017; Lewis et al. 2017). RDDs observed and women's respiratory

520 symptoms, in various indoor microenvironment shows positive correlations between PM

521 values and their symptoms. The health result survey and RDDs values (Tables 1 and Fig 5) in

522 different microenvironments confirmed these results. 


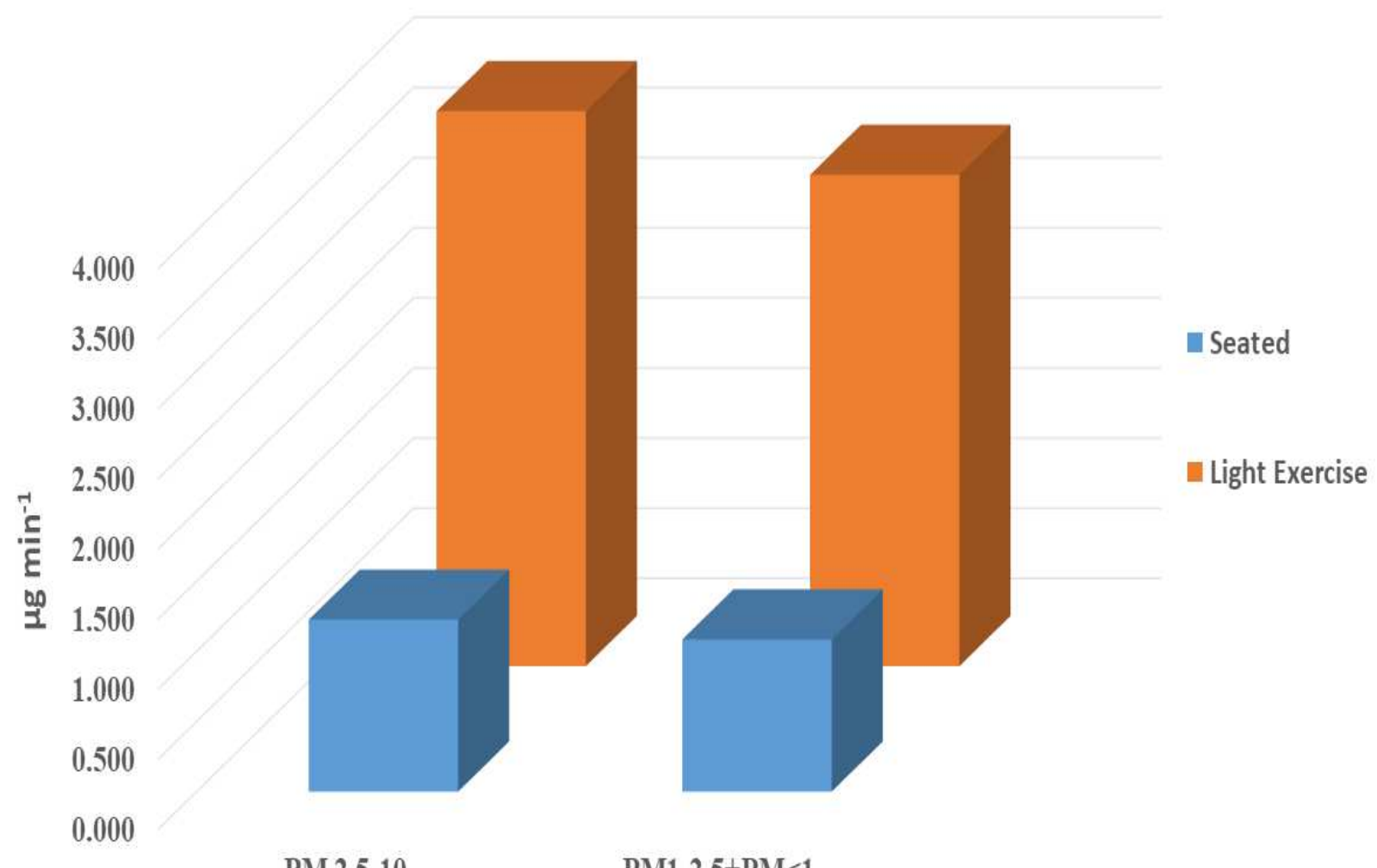

524 Fig 7: Rdds due to Coarser $\left(\mathbf{P M}_{10}\right)$ and Fine particles $\left(\mathbf{P M}_{2.5}+\mathbf{P M}_{1}\right)$.

\section{$525 \quad 3.5$ Health risk assessment}

526 The Exposure Index (EI) was calculated by considering $\mathrm{PM}_{10} \& \mathrm{PM}_{2.5}$ concentrations in various

527 microenvironments associated with different time patterns and activity records. An EI was

528 established based on PM concentrations, showing maximum exposure level in coal users succeed by kerosene and LPG users. The average EI in different locations varies as the women in various areas spend different time in cooking and other activities. The EI was calculated with the aim of determining how much exposure will occur inside the house based on the amount of time spent in various microenvironments.

533 The results show that the EI is more in the Dhaiya slum with value $8.23 \pm 1.97 \& 6.77 \pm 1.32$ for $534 \mathrm{PM}_{10} \& \mathrm{PM}_{2.5}$ as they use solid fuel and have an enclosed kitchen with a compact living area 535 (Fig 8). The EI demonstrates that the use of coal has a significant effect on the main cook's 536 health in a kitchen. In different time patterns, PM concentrations indicate that exposure affects 537 participants not only during cooking hours but also during non-cooking hours, as particles accumulate in the indoor environment. While the reported EI was lower in the fields of analysis, 
539

540

541

the exposure index was still higher than the WHO's standard guidelines (2014). (Sidhu et al. 2017) recorded higher EI values among Indian SBF users than the present study. Detailed information on the EI calculations is provided in Table S3.

12.00

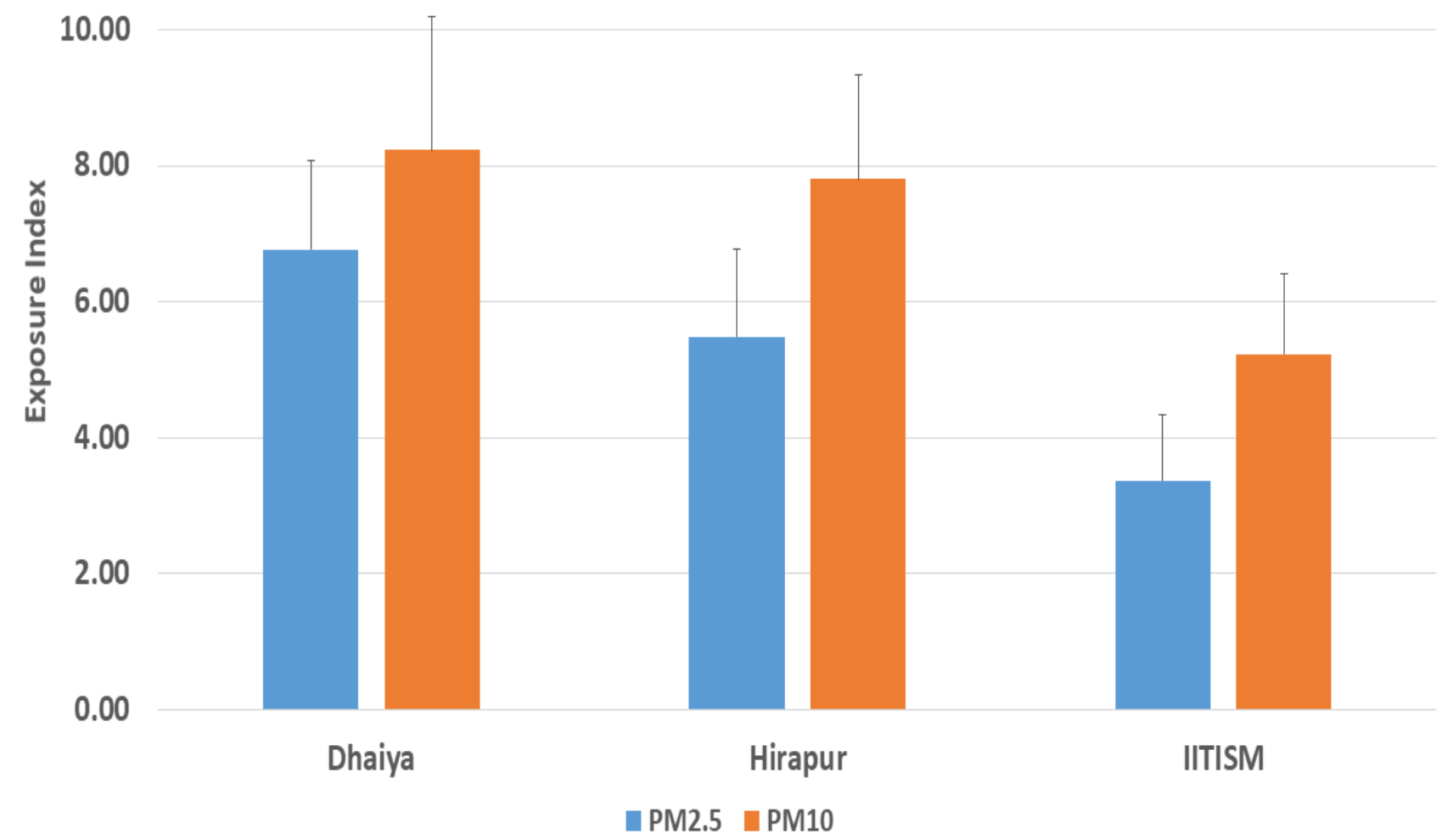

542

543 Fig 8: Exposure Index in different locations.

544 Intake concentration for $\mathrm{PM}_{2.5}$ in Dhaiya $\left(132.51 \mu \mathrm{g} / \mathrm{m}^{3}, 95 \%\right.$ CI: 94.62, 170.39) was almost

5451.5 times higher than IIT(ISM) Women's $\left(83.29 \mu \mathrm{g} / \mathrm{m}^{3}, 95 \%\right.$ CI: 50.98, 115.61). The HQ values

546 for $\mathrm{PM}_{2.5}$ found more elevated in the Dhaiya (5.30, 95\% CI: 3.79, 6.82), followed by Hirapur

$547(5.09,95 \%$ CI: 3.82, 6.37) and IIT(ISM) areas with a value (3.33, 95\% CI: 2.04, 4.62) as shown

548 in Table 3. Whereas Intake concentration for $\mathrm{PM}_{10}$ in Dhaiya $\left(218.28 \mu \mathrm{g} / \mathrm{m}^{3}, 95 \%\right.$ CI: 159.67 ,

549 276.89) was higher than IIT(ISM) Women's $\left(107.21 \mu \mathrm{g} / \mathrm{m}^{3}, 95 \%\right.$ CI: 70.11, 144.28). The same

550 trend follows for the HQ values for $\mathrm{PM}_{10}$ as $\mathrm{PM}_{2.5}$, which found more in the Dhaiya (4.36, 95\%

551 CI: 3.19, 5.53), followed by Hirapur (4.06, 95\% CI: 3.01, 5.10) and IIT(ISM) areas with a value

552 (2.14, 95\% CI: 1.40, 2.86).

553 Table 3: Intake concentration (IC) and Hazard quotient (HQ) in different Locations

\begin{tabular}{|l|l|l|l|}
\hline Location & IC $\left(\mu \mathrm{g} / \mathrm{m}^{3}\right)$ & RfC $\left(\mu \mathrm{g} / \mathrm{m}^{3}\right)$ & HQ \\
\hline
\end{tabular}




\begin{tabular}{|l|l|l|l|l|l|l|}
\hline & $\mathbf{P M}_{2.5}$ & $\mathbf{P M}_{10}$ & $\mathbf{P M}_{2.5}$ & $\mathbf{P M}_{10}$ & $\mathbf{P M}_{2.5}$ & $\mathbf{P M}_{10}$ \\
\hline Dhaiya & $132.51 \pm 105.08$ & $218.28 \pm 144.33$ & 25 & 50 & $5.31 \pm 4.21$ & $4.37 \pm 2.36$ \\
\hline Hirapur & $127.37 \pm 64.18$ & $202.87 \pm 117.87$ & 25 & 50 & $5.09 \pm 2.57$ & $4.06 \pm 2.89$ \\
\hline IIT(ISM) & $83.29 \pm 53.47$ & $107.19 \pm 61.37$ & 25 & 50 & $3.33 \pm 2.13$ & $2.14 \pm 1.23$ \\
\hline
\end{tabular}

Potential toxicological risk of $\mathrm{PM}_{10} \& \mathrm{PM}_{2.5}$ due to fuel use and cooking period was found significant in different study areas. Residents using coal were found to have a higher health risk than residents using clean fuels (LPG) as defined by the hazard ratio of different residential areas (Fig 8). The findings are also confirmed by the outcome of a questionnaire study. A related risk assessment for $\mathrm{PM}_{2.5}$ was performed by (Sidhu et al. 2017) to quantify the health risk from SBF burning among women. The results of that study indicates that women were exposed to higher levels of $\mathrm{PM}_{2.5}$, resulting in them being at a higher toxicological risk. The results of this research suggest that coal users were subject to elevated intake concentrations of $\mathrm{PM}_{10}$ and $\mathrm{PM}_{2.5}$, which may lead to the early development of various respiratory diseases and poses a high risk to those who are already ill with diminished lung capacity (Jena and Singh 2017; Li et al. 2017) and premature deaths due to HAP (Suk et al. 2016; Jindal et al. 2020).

\section{Discussion}

There is barely any systematic study on the effect of a household's IAQ, conducted in the Indian context that calculated $\mathrm{PM}_{1}$ concentrations in conjunction with $\mathrm{PM}_{2.5} \& \mathrm{PM}_{10}$ under different field variables (fuel and cook-stove used, kitchen characteristics, duration of cooking, and time spent in indoor conditions, etc).

571 Table 4 indicates the relation of PM concentration of the present study with other previously performed research to approximate the IAQ / HAP. Comparing HAP measurements during actual cooking hours was hardly performed in India, except for a report by (Deepthi et al. 2019) in Telangana and (Sidhu et al. 2017) in Punjab. (Deepthi et al. 2019) recorded 24 h average $\mathrm{PM}_{10}, \mathrm{PM}_{2.5}$ and $\mathrm{PM}_{1}$ values of $176.69,94.96,63.42 \mu \mathrm{g} / \mathrm{m}^{3}$, while 1891,1481 and $767.5 \mu \mathrm{g} / \mathrm{m}^{3}$ for cooking hours. Besides, this study found that the use of Solid Biomass Fuel (SBF) in indoor

577 kitchens raises $\mathrm{PM}_{10}, \mathrm{PM}_{2.5}, \mathrm{PM}_{1}\left(425,278\right.$, and $\left.176 \mu \mathrm{g} / \mathrm{m}^{3}\right)$ up to 10 times relative to outdoor 578 kitchens due to inadequate ventilation. (Sidhu et al. 2017) analyzed the concentrations of $\mathrm{PM}_{2.5}$ 579 in five different kitchens type using various fuels and recorded the maximum values of 697 580 $\mu \mathrm{g} / \mathrm{m}^{3}$ in the closed kitchen followed by $540 \mu \mathrm{g} / \mathrm{m}^{3}$ in the outdoor kitchen. (Sharma and Jain 2019) reported that the $24 \mathrm{~h}$ average $\mathrm{PM}_{10}$ was $908,542,479 \mu \mathrm{g} / \mathrm{m}^{3}$, respectively, in an 
enclosed, semi-enclosed, and open kitchen. Likewise, $\mathrm{PM}_{2.5}$ \& $\mathrm{PM}_{1}$ were assessed as 351, 268, $112 \mu \mathrm{g} / \mathrm{m}^{3}$ and 239, 195, $71 \mu \mathrm{g} / \mathrm{m}^{3}$ respectively. However, (Nayek and Padhy 2018) also recorded that $\mathrm{PM}_{2.5}$ concentrations in different kitchen types and found $185 \mu \mathrm{g} / \mathrm{m}^{3}$ in more than $75 \%$ of open kitchens compared to $2055 \mu \mathrm{g} / \mathrm{m}^{3}$ in less than $25 \%$ of open kitchens in rural areas of West Bengal. (Ojo et al. 2015) and (Grabow et al. 2013) have validated that improved kitchen ventilation resulted in substantial PM emission reductions. Furthermore, by comparing with NAAQS for PM, (Massey et al. 2013) reported that levels were 3.6-4 times and 4.5-5 times higher for $\mathrm{PM}_{10} \& \mathrm{PM}_{2.5}$, respectively. $\mathrm{PM}_{2.5}$ concentration was reported $577 \mu \mathrm{g} / \mathrm{m}^{3}$ and $774 \mu \mathrm{g} / \mathrm{m}^{3}$ for places Rajasthan (Jaipur) and Haryana (Jhajjar), respectively, comparable findings were observed in the presented study. From global studies, a study (Smith and Mehta 2003) based on $\mathrm{PM}_{2.5}$ concentration in Guatemalan village showed the value exceeded 5000 $\mu \mathrm{g} / \mathrm{m}^{3}$ for open fire whereas (Mishra 2003) reported $2000 \mu \mathrm{g} / \mathrm{m}^{3}$ values were measured in Zimbabwe village for the same. (Begum et al. 2009) observed that mean $\mathrm{PM}_{10}$ concentrations were $132 \mu \mathrm{g} / \mathrm{m}^{3}$ and $63 \mu \mathrm{g} / \mathrm{m}^{3}$ for indoor and outdoor, respectively, during the Bangladesh study, which was roughly two times lower than our research. In Nepal, the PM2.5 values for households using open fire reached $8000 \mu \mathrm{g} / \mathrm{m}^{3}$, while households using kerosene surpassed $3000 \mu \mathrm{g} / \mathrm{m}^{3}$ (Lohani 2011) which is around two to four times higher than our studies. Similar concentrations were found in this sample with the experiments in Nepal and Kenya recorded concentrations of $\mathrm{PM}_{2.5}$ in cooking hours ranging from 650 to $4200 \mu \mathrm{g} / \mathrm{m}^{3}$. Variations reported can be clarified by factors such as the sampling method used, regional variation, cooking habits and pattern, kitchen configurations, and household structure with ventilation arrangements. This work also identifies higher concentrations of contaminants in the household throughout cooking periods. However, concentrations were found to be comparable to other research (Balakrishnan et al. 2013; Chakraborty et al. 2014; Muralidharan et al. 2015). Such findings affirm the results of this study and are in good agreement showing substantial effects on household air quality from the fuel used and kitchen functions.

Table 4: PM (PM10, $\mathrm{PM}_{2.5}$, and $\left.\mathrm{PM}_{1}\right)$, RDD, and EI identified in different households in previous studies and in this study

\begin{tabular}{|l|l|l|l|}
\hline Place & Parameter & Major Finding & Reference \\
\hline
\end{tabular}




\begin{tabular}{|c|c|c|c|}
\hline Dhanbad, India & $\begin{array}{l}\mathrm{PM}_{10} \\
\mathrm{PM}_{2.5} \\
\mathrm{PM}_{1} \\
\mathrm{RDD}, \mathrm{EI}\end{array}$ & $\begin{array}{c}185.12 \pm 127.23 \mu \mathrm{g} / \mathrm{m}^{3} \\
115.31 \pm 91.56 \mu \mathrm{g} / \mathrm{m}^{3} \\
74.68 \pm 54.67 \mu \mathrm{g} / \mathrm{m}^{3} \\
3.795 \mu \mathrm{gmin}^{-1}\left(\mathrm{PM}_{10}\right) \\
2.078 \mu \mathrm{gmin}^{-1}\left(\mathrm{PM}_{2.5}\right) \\
0.603 \mu \mathrm{gmin}^{-1}\left(\mathrm{PM}_{10}\right)\end{array}$ & This study \\
\hline Telangana, India & $\begin{array}{l}\mathrm{PM}_{10} \\
\mathrm{PM}_{2.5} \\
\mathrm{PM}_{1}\end{array}$ & $\begin{array}{l}\text { 24h average } \\
176.69 \mu \mathrm{g} / \mathrm{m}^{3} \\
94.96 \mu \mathrm{g} / \mathrm{m}^{3} \\
63.42 \mu \mathrm{g} / \mathrm{m}^{3}\end{array}$ & $\begin{array}{l}\text { (Deepthi et al. } \\
\text { 2019) }\end{array}$ \\
\hline $\begin{array}{l}\text { West Bengal, } \\
\text { India }\end{array}$ & $\mathrm{PM}_{2.5}$ & $\begin{array}{l}185 \mu \mathrm{g} / \mathrm{m}^{3} \text { in more than } 75 \% \text { open } \\
\text { kitchens } \\
2055 \mu \mathrm{g} / \mathrm{m}^{3} \text { in less than } 25 \% \text { open } \\
\text { kitchens }\end{array}$ & $\begin{array}{l}\text { (Nayek and Padhy } \\
\text { 2018) }\end{array}$ \\
\hline Punjab, India & $\begin{array}{l}\mathrm{PM}_{2.5} \\
\text { EI }\end{array}$ & $\begin{array}{l}\mathrm{PM}_{2.5}: 697 \mu \mathrm{g} / \mathrm{m}^{3} \text { (closed kitchen) } \\
\mathrm{PM}_{2.5}: 540 \mu \mathrm{g} / \mathrm{m}^{3} \text { (outdoor kitchen) } \\
\text { EI:23(Biomass),7(Lpg):closed kitchen } \\
\text { EI:12(Biomass),7(Lpg):outdoor } \\
\text { kitchen }\end{array}$ & (Sidhu et al. 2017) \\
\hline Agra, India & $\begin{array}{l}\mathrm{PM}>2.5 \\
\mathrm{PM}_{2.5-1.0} \\
\mathrm{PM}_{1.0-0.5} \\
\mathrm{PM}_{0.5-0.25}\end{array}$ & $\begin{array}{l}\text { Mean } \pm \mathrm{SD} \\
106.01 \pm 21.21 \mu \mathrm{g} / \mathrm{m}^{3} \\
47.68 \pm 10.06 \mu \mathrm{g} / \mathrm{m}^{3} \\
29.98 \pm 12.30 \mu \mathrm{g} / \mathrm{m}^{3} \\
54.08 \pm 16.30 \mu \mathrm{g} / \mathrm{m}^{3}\end{array}$ & (Rohra et al. 2018) \\
\hline Bangladesh & $\mathrm{PM}_{10}$ & $\begin{array}{l}132 \mu \mathrm{g} / \mathrm{m}^{3} \text { indoor } \\
63 \mu \mathrm{g} / \mathrm{m}^{3} \text { outdoor }\end{array}$ & $\begin{array}{l}\text { (Begum et al. } \\
2009)\end{array}$ \\
\hline Nepal & $\mathrm{PM}_{2.5}$ & $\begin{array}{l}8000 \mu \mathrm{g} / \mathrm{m}^{3} \text { (open fire) } \\
3000 \mu \mathrm{g} / \mathrm{m}^{3} \text { (kerosene) }\end{array}$ & (Lohani 2011) \\
\hline Sau poulo, Brazil & $\begin{array}{l}\mathrm{PM}_{2.5-10} \\
\mathrm{PM}_{1-2.5} \\
\mathrm{PM}_{<1} \\
\mathrm{RDD}\end{array}$ & 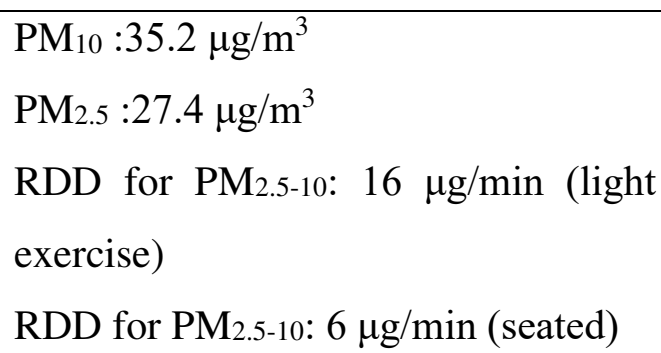 & $\begin{array}{l}\text { (Segalin et al. } \\
\text { 2017) }\end{array}$ \\
\hline
\end{tabular}




\begin{tabular}{|l|l|l|l|}
\hline Honduras & PM $_{2.5}$ & $\begin{array}{l}\text { Cook stoves type : Mean (SD), 24 h } \\
\text { Justa: 76 (51) } \mu \mathrm{g} / \mathrm{m}^{3} \\
\text { Traditional: } 263(386) \mu \mathrm{g} / \mathrm{m}^{3},\end{array}$ & $\begin{array}{l}\text { (Benka-Coker et } \\
\text { al. 2020) }\end{array}$ \\
\hline Sanghai, China & PM$_{2.5}$ & $\begin{array}{l}\text { Cooking hour } \\
\text { Average: } 183.64(46.51) \mu \mathrm{g} / \mathrm{m}^{3}, \\
\text { Peak: } 800-1000 \mu \mathrm{g} / \mathrm{m}^{3}\end{array}$ & (Zeng et al. 2020) \\
& & & \\
\hline
\end{tabular}

611 Outcomes based on the present study depict the alarming micro-environmental conditions in 612 the study area. The woman in Dhanbad city is susceptible to higher particle doses during the 613 cooking period. Women both in working conditions in household and resting positions suffer 614 asymmetric exposure of PM concentrations. These findings suggest that women in the 615 household within proximity of the main road with heavy vehicular density and lack of proper 616 ventilation conditions are exposed to higher fine particle concentration. These all size 617 segregated PM concentrations result in higher RDDs in all the $3 \mathrm{HD}$, TB, and AL regions in 618 this vicinity. The average exposure index in different locations varies, as the women in various 619 areas are associated with different time patterns and activity records. The present study based 620 on women within the household of Dhanbad city advised that proper ventilation in houses and 621 the intermittent cooking procedure can lessen the dust deposition. Suitable design for ventilations, household structure, cooking duration and pattern, cooking stoves and fuel selection, indoor-outdoor interaction, Socio-Economical status, and awareness towards Public health are various key areas to be considered for lower respiratory dust depositions in people residing indoor conditions. As the exposed population group (women) in the study area is more susceptible to HAP, remediation actions will be essential. Our findings of indoor PM conditions in the household with their exposure index, and inevitably, their adverse health impact will be helpful for remediation action against poor household quality. This research will help the scientific community and policymakers quantify the extent to which household air pollution is responsible for the most vulnerable section of society, i.e. women, who experience disproportionate exposure to and consequences of air pollution. For specific sources and elemental analysis of size segregated PM, further investigation is recommended.

\section{Declarations:}

634 Ethics approval and consent to participate: "Not applicable" 
635 Consent for publication: Informed consent was obtained from all subjects involved in the study.

Availability of data and materials: Supplementary data is attached with this manuscript. The data presented in this study are also available on request from the corresponding authors.

639 Competing interests: "The authors declare that they have no competing interests".

640 Funding: "This research received no external funding"

641 Author Contributions: Conceptualization, M. K. J (Manish Kumar Jain) and S.K (Shravan 642 Kumar); methodology, S.K (Shravan Kumar); monitoring, S.K (Shravan Kumar); supervision, 643 M. K. J (Manish Kumar Jain); formal analysis, S.K (Shravan Kumar); data interpretations, S.K 644 (Shravan Kumar) and M. K. J (Manish Kumar Jain) ; writing-original draft preparation, S.K 645 (Shravan Kumar); writing - review and editing, M. K. J (Manish Kumar Jain) and S.K 646 (Shravan Kumar). All authors have read and agreed to the published version of the manuscript.

\section{Acknowledgments}

648 The authors are very pleased to thanks the Department of Environmental Science and 649 Engineering, IIT(ISM) Dhanbad, for ensuring logistical resources. We acknowledge the regional center of two state agencies, Jharkhand State Pollution Control Board and the Jharkhand Space Association Center, for providing salient meteorological and background data. We also thank the female volunteers in the study area for their assistance and cooperative approach with the questionnaire survey. The authors acknowledge Mr. Vivek Singh and Ms. Silvia Dutta (Research Scholars) from the Department of Environmental Science and Engineering, IIT (ISM) Dhanbad, for their support for study area map development.

\section{Reference}

Adesina JA, Piketh SJ, Qhekwana M, et al (2020) Contrasting indoor and ambient particulate matter concentrations and thermal comfort in coal and non-coal burning households at South Africa Highveld. Sci Total Environ 699:134403. https://doi.org/10.1016/j.scitotenv.2019.134403

Alim MA, Sarker MAB, Selim S, et al (2014) Respiratory involvements among women exposed to the smoke of traditional biomass fuel and gas fuel in a district of Bangladesh. 
665

Arbex MA, Santos U de P, Martins LC, et al (2012) A poluição do ar e o sistema respiratório. J Bras Pneumol 38:643-655. https://doi.org/10.1590/S1806-37132012000500015

Avila-Tang E, Elf JL, Cummings KM, et al (2013) Assessing secondhand smoke exposure with reported measures. Tob Control 22:156-163. https://doi.org/10.1136/tobaccocontrol-2011-050296

Azarmi F, Kumar P (2016) Ambient exposure to coarse and fine particle emissions from building demolition. Atmos Environ 137:62-79. https://doi.org/10.1016/j.atmosenv.2016.04.029

Bai L, He Z, Li C, Chen Z (2020) Investigation of yearly indoor/outdoor PM2.5 levels in the perspectives of health impacts and air pollution control: Case study in Changchun, in the northeast of China. Sustain Cities Soc 53:101871. https://doi.org/10.1016/j.scs.2019.101871

Balakrishnan K, Ghosh S, Ganguli B, et al (2013) State and national household concentrations of PM2.5 from solid cookfuel use: Results from measurements and modeling in India for estimation of the global burden of disease. Environ Heal A Glob Access Sci Source 12:1-14. https://doi.org/10.1186/1476-069X-12-77

Barnes B, Mathee A, Thomas E (2011) The impact of health behaviour change intervention on indoor air pollution indicators in the rural North West Province, South Africa. $\mathbf{J}$ Energy South Africa 22:35-44. https://doi.org/10.17159/2413-3051/2011/v22i3a3220

Beelen R, Raaschou-Nielsen O, Stafoggia M, et al (2014a) Effects of long-term exposure to air pollution on natural-cause mortality: An analysis of 22 European cohorts within the multicentre ESCAPE project. Lancet 383:785-795. https://doi.org/10.1016/S01406736(13)62158-3

Beelen R, Raaschou-Nielsen O, Stafoggia M, et al (2014b) Effects of long-term exposure to air pollution on natural-cause mortality: An analysis of 22 European cohorts within the multicentre ESCAPE project. Lancet. https://doi.org/10.1016/S0140-6736(13)62158-3

Begum BA, Paul SK, Dildar Hossain M, et al (2009) Indoor air pollution from particulate matter emissions in different households in rural areas of Bangladesh. Build Environ 44:898-903. https://doi.org/10.1016/j.buildenv.2008.06.005 
Benka-Coker ML, Peel JL, Volckens J, et al (2020) Kitchen concentrations of fine particulate matter and particle number concentration in households using biomass cookstoves in rural Honduras. Environ Pollut 258:113697. https://doi.org/10.1016/j.envpol.2019.113697

Bhole DV (2017) Implications of Household Air Pollution in India on Health: Need of health technology. Int J Healthc Educ Med Informatics 4:18-22. https://doi.org/10.24321/2455.9199.201702

Bird DK (2009) The use of questionnaires for acquiring information on public perception of natural hazards and risk mitigation - A review of current knowledge and practice. Nat Hazards Earth Syst Sci 9:1307-1325. https://doi.org/10.5194/nhess-9-1307-2009

Bluyssen PM, Roda C, Mandin C, et al (2016) Self-reported health and comfort in "modern" office buildings: First results from the European OFFICAIR study. Indoor Air 26:298317. https://doi.org/10.1111/ina.12196

Burkart J, Steiner G, Reischl G, et al (2010) Characterizing the performance of two optical particle counters (Grimm OPC1.108 and OPC1.109) under urban aerosol conditions. J Aerosol Sci 41:953-962. https://doi.org/10.1016/j.jaerosci.2010.07.007

Chakraborty D, Mondal NK, Datta JK (2014) Indoor pollution from solid biomass fuel and rural health damage: A micro-environmental study in rural area of Burdwan, West Bengal. Int J Sustain Built Environ 3:262-271. https://doi.org/10.1016/j.ijsbe.2014.11.002

Chao CY, Wong KK (2002) Residential indoor PM 10 and PM 2.5 in Hong Kong and the elemental composition

Chen Y, Shen G, Huang Y, et al (2016) Household air pollution and personal exposure risk of polycyclic aromatic hydrocarbons among rural residents in Shanxi, China. Indoor Air 26:246-258. https://doi.org/10.1111/ina.12204

Daigle CC, Chalupa DC, Gibb FR, et al (2003) in Humans During Rest and Exercise. Children 15:539-552. https://doi.org/10.1080/08958370390205065

Datta A, Suresh R, Gupta A, et al (2017) Indoor air quality of non-residential urban buildings in Delhi, India. Int J Sustain Built Environ 6:412-420. https://doi.org/10.1016/j.ijsbe.2017.07.005 
de la Sota C, Lumbreras J, Pérez N, et al (2018) Indoor air pollution from biomass cookstoves in rural Senegal. Energy Sustain Dev 43:224-234. https://doi.org/10.1016/j.esd.2018.02.002

Deepthi Y, Shiva Nagendra SM, Gummadi SN (2019) Characteristics of indoor air pollution and estimation of respiratory dosage under varied fuel-type and kitchen-type in the rural areas of Telangana state in India. Sci Total Environ 650:616-625. https://doi.org/10.1016/j.scitotenv.2018.08.381

Dolk H, Armstrong B, Lachowycz K, et al (2010) Ambient air pollution and risk of congenital anomalies in England, 1991-1999. Occup Environ Med 67:223-227. https://doi.org/10.1136/oem.2009.045997

Evans J, van Donkelaar A, Martin R V., et al (2013) Estimates of global mortality attributable to particulate air pollution using satellite imagery. Environ Res 120:33-42. https://doi.org/10.1016/j.envres.2012.08.005

Ferro AR, Kopperud RJ, Hildemann LM (2004) Elevated personal exposure to particulate matter from human activities in a residence. J Expo Anal Environ Epidemiol 14:. https://doi.org/10.1038/sj.jea.7500356

Forum RA (2019) Guidelines for Human Exposure Assessment Guidelines for Human Exposure Assessment

Fullerton DG, Bruce N, Gordon SB (2008) Indoor air pollution from biomass fuel smoke is a major health concern in the developing world. Trans R Soc Trop Med Hyg 102:843851. https://doi.org/10.1016/j.trstmh.2008.05.028

Grabow K, Still D, Bentson S (2013) Test kitchen studies of indoor air pollution from biomass cookstoves. Energy Sustain Dev 17:458-462. https://doi.org/10.1016/j.esd.2013.05.003

Guo H, Lee SC, Chan LY, Li WM (2004) Risk assessment of exposure to volatile organic compounds in different indoor environments. Environ Res 94:57-66. https://doi.org/10.1016/S0013-9351(03)00035-5

Gupta SK, Elumalai SP (2017) Size-segregated particulate matter and its association with respiratory deposition doses among outdoor exercisers in Dhanbad City, India. J Air Waste Manag Assoc 67:1137-1145. https://doi.org/10.1080/10962247.2017.1344159 
Heal MR, Kumar P, Harrison RM (2012) Particles, air quality, policy and health. Chem Soc Rev 41:6606-6630. https://doi.org/10.1039/C2CS35076A

Hime NJ, Marks GB, Cowie CT (2018) A comparison of the health effects of ambient particulate matter air pollution from five emission sources. Int. J. Environ. Res. Public Health 15

Hinds WC Aerosol Technology Properties, Behavior, and Measurement ofAirborne Particles Second Edition

Human OOF (2019) HUMAN HEALTH RISK ASSESSMENT ( HHRA ) NOTE NUMBER 1. $1-5$

Hystad P, Villeneuve PJ, Goldberg MS, et al (2015) Exposure to traffic-related air pollution and the risk of developing breast cancer among women in eight Canadian provinces: A case-control study. Environ Int 74:240-248. https://doi.org/10.1016/j.envint.2014.09.004

Jain S (2017) Exposure to in-vehicle respirable particulate matter in passenger vehicles under different ventilation conditions and seasons. Sustain Environ Res 27:87-94. https://doi.org/10.1016/j.serj.2016.08.006

Jaques PA, Kim CS (2000) MEASUREMENT OF TOTAL LUNG DEPOSITION OF INHALED ULTRAFINE PARTICLES IN HEALTHY MEN AND WOMEN

Jena S, Singh G (2017) Human health risk assessment of airborne trace elements in Dhanbad, India. Atmos Pollut Res 8:490-502. https://doi.org/10.1016/j.apr.2016.12.003

Jindal SK, Aggarwal AN, Jindal A (2020) Household air pollution in India and respiratory diseases: Current status and future directions. Curr Opin Pulm Med 26:128-134. https://doi.org/10.1097/MCP.0000000000000642

Kesavachandran CN, Kamal R, Bihari V, et al (2015) Particulate matter in ambient air and its association with alterations in lung functions and respiratory health problems among outdoor exercisers in national capital region, India. Atmos Pollut Res 6:618-625. https://doi.org/10.5094/APR.2015.070

Kumar P, Goel A (2016a) Concentration dynamics of coarse and fine particulate matter at and around signalised traffic intersections. Environ Sci Process Impacts 18:1220-1235. https://doi.org/10.1039/c6em00215c 
Kumar P, Goel A (2016b) Concentration dynamics of coarse and fine particulate matter at and around signalised traffic intersections. Environ Sci Process Impacts 18:1220-1235. https://doi.org/10.1039/c6em00215c

Kurt-Karakus PB (2012) Determination of heavy metals in indoor dust from Istanbul, Turkey: Estimation of the health risk. Environ Int 50:47-55. https://doi.org/10.1016/j.envint.2012.09.011

Lewis JJ, Hollingsworth JW, Chartier RT, et al (2017) Biogas Stoves Reduce Firewood Use, Household Air Pollution, and Hospital Visits in Odisha, India. Environ Sci Technol 51:560-569. https://doi.org/10.1021/acs.est.6b02466

Li Q, Jiang J, Wang S, et al (2017) Impacts of household coal and biomass combustion on indoor and ambient air quality in China: Current status and implication. Sci Total Environ 576:347-361. https://doi.org/10.1016/j.scitotenv.2016.10.080

Liao J, Ye W, Pillarisetti A, Clasen TF (2019) Modeling the impact of an indoor air filter on air pollution exposure reduction and associated mortality in Urban Delhi household. Int J Environ Res Public Health 16:. https://doi.org/10.3390/ijerph16081391

Lohani SP (2011) Biomass as a Source of Household Energy and Indoor Air Pollution in Nepal. Iran J Energy Environ 2:74-78

Loomis D, Huang W, Chen G (2014) The International Agency for Research on Cancer (IARC) evaluation of the carcinogenicity of outdoor air pollution: Focus on China. Chin J Cancer 33:189-196. https://doi.org/10.5732/cjc.014.10028

Massey DD, Kulshrestha A, Taneja A (2013) Particulate matter concentrations and their related metal toxicity in rural residential environment of semi-arid region of India. Atmos Environ 67:278-286. https://doi.org/10.1016/j.atmosenv.2012.11.002

Mehta AJ, Zanobetti A, Bind MAC, et al (2016) Long-term exposure to ambient fine particulate matter and renal function in older men: The veterans administration normative aging study. Environ Health Perspect 124:1353-1360. https://doi.org/10.1289/ehp.1510269

Mishra V (2003) Indoor air pollution from biomass combustion and acute respiratory illness in preschool age children in Zimbabwe. Int J Epidemiol 32:847-853. https://doi.org/10.1093/ije/dyg240 
Morris et al. 2012 (2012) 基因的改变NIH Public Access. Bone 23:1-7. https://doi.org/10.1038/jid.2014.371

Muralidharan V, Sussan TE, Limaye S, et al (2015) Field testing of alternative cookstove performance in a rural setting of Western India. Int J Environ Res Public Health 12:1773-1787. https://doi.org/10.3390/ijerph120201773

Nayek S, Padhy PK (2018) Approximation of personal exposure to fine particulate matters (PM2.5) during cooking using solid biomass fuels in the kitchens of rural West Bengal, India. Environ Sci Pollut Res 25:15925-15933. https://doi.org/10.1007/s11356-018$1831-7$

Ojo KD, Soneja SI, Scrafford CG, et al (2015) Indoor particulate matter concentration, water boiling time, and fuel use of selected alternative cookstoves in a home-like setting in rural Nepal. Int J Environ Res Public Health 12:7558-7581. https://doi.org/10.3390/ijerph120707558

Olmo NRS, Saldiva PH do N, Braga ALF, et al (2011) A review of low-level air pollution and adverse effects on human health: Implications for epidemiological studies and public policy. Clinics 66:681-690. https://doi.org/10.1590/S1807-59322011000400025

Pandey VL, Chaubal A (2011) Comprehending household cooking energy choice in rural India. Biomass Bioenergy - BIOMASS BIOENERG 35: https://doi.org/10.1016/j.biombioe.2011.09.020

Pant P, Guttikunda SK, Peltier RE (2016) Exposure to particulate matter in India: A synthesis of findings and future directions. Environ. Res.

Paulin L, Hansel N (2016) Particulate air pollution and impaired lung function. F1000Research 5:1-9. https://doi.org/10.12688/f1000research.7108.1

Prabhu V, Gupta SK, Madhwal S, Shridhar V (2019a) Exposure to Atmospheric Particulates and Associated Respirable Deposition Dose to Street Vendors at the Residential and Commercial Sites in Dehradun City. Saf Health Work 10:237-244. https://doi.org/10.1016/j.shaw.2019.01.005

Prabhu V, Gupta SK, Madhwal S, Shridhar V (2019b) Exposure to Atmospheric Particulates and Associated Respirable Deposition Dose to Street Vendors at the Residential and Commercial Sites in Dehradun City. Saf Health Work. 
Rohra H, Tiwari R, Khandelwal N, Taneja A (2018) Mass distribution and health risk assessment of size segregated particulate in varied indoor microenvironments of Agra, India - A case study. Urban Clim 24:139-152. https://doi.org/10.1016/j.uclim.2018.01.002

Sánchez-soberón F, Mari M, Kumar V, et al (2015) An approach to assess the Particulate Matter exposure for the population living around a cement plant : modelling indoor air and particle deposition in the respiratory tract. Environ Res 143:10-18. https://doi.org/10.1016/j.envres.2015.09.008

Segalin B, Kumar P, Micadei K, et al (2017) Size-segregated particulate matter inside residences of elderly in the Metropolitan Area of São Paulo, Brazil. Atmos Environ 148:139-151. https://doi.org/10.1016/j.atmosenv.2016.10.004

Sharma D, Jain S (2019) Impact of intervention of biomass cookstove technologies and kitchen characteristics on indoor air quality and human exposure in rural settings of India. Environ Int 123:240-255. https://doi.org/10.1016/j.envint.2018.11.059

Sharma R, Balasubramanian R (2018) Size-fractionated particulate matter in indoor and outdoor environments during the 2015 haze in Singapore: Potential human health risk assessment. Aerosol Air Qual Res 18:904-917. https://doi.org/10.4209/aaqr.2017.11.0515

Sidhu MK, Ravindra K, Mor S, John S (2017) Household air pollution from various types of rural kitchens and its exposure assessment. Sci Total Environ 586:419-429. https://doi.org/10.1016/j.scitotenv.2017.01.051

Simoni M, Scognamiglio A, Carrozzi L, et al (2004) Indoor exposures and acute respiratory effects in two general population samples from a rural and an urban area in Italy. J Expo Anal Environ Epidemiol 14 Suppl 1:S144-52. https://doi.org/10.1038/sj.jea.7500368

Singh S, Tiwari S, Gond DP, et al (2015a) Intra-seasonal variability of black carbon aerosols over a coal field area at Dhanbad, India. Atmos Res. https://doi.org/10.1016/j.atmosres.2015.03.015

Singh S, Tiwari S, Gond DP, et al (2015b) Intra-seasonal variability of black carbon aerosols over a coal field area at Dhanbad, India. Atmos Res 161-162:25-35. 
Smith K (2000) National burden of disease in India from indoor air pollution. Proc Natl Acad Sci U S A 97:13286-13293. https://doi.org/10.1073/pnas.97.24.13286

Smith KR, Mehta S (2003) The burden of disease from indoor air pollution in developing countries: Comparison of estimates. Int J Hyg Environ Health 206:279-289. https://doi.org/10.1078/1438-4639-00224

Stanaway JD, Afshin A, Gakidou E, et al (2018) Global, regional, and national comparative risk assessment of 84 behavioural, environmental and occupational, and metabolic risks or clusters of risks for 195 countries and territories, 1990-2017: A systematic analysis for the Global Burden of Disease Stu. Lancet 392:1923-1994. https://doi.org/10.1016/S0140-6736(18)32225-6

Suk WA, Ahanchian H, Asante KA, et al (2016) Environmental pollution: An underrecognized threat to children's health, especially in low- and middle-income countries. Environ Health Perspect 124:A43-A45. https://doi.org/10.1289/ehp.1510517

The Census of India (2011) The Census of india 2011 report pdf. Goi

Tian J, Ni H, Cao J, et al (2017) Characteristics of carbonaceous particles from residential coal combustion and agricultural biomass burning in China. Atmos Pollut Res 8:521527. https://doi.org/10.1016/j.apr.2016.12.006

Varghese SK, Gangamma S, Patil RS, Sethi V (2005) Particulate respiratory dose to Indian women from domestic cooking. Aerosol Sci Technol 39:1201-1207. https://doi.org/10.1080/02786820500444838

Weuve J, Puett RC, Schwartz J, et al (2012) Exposure to particulate air pollution and cognitive decline in older women. Arch Intern Med 172:219-227. https://doi.org/10.1001/archinternmed.2011.683

WHO (2011) Global database of household air pollution measurements. 2014:1-2

Wu F, Jacobs D, Mitchell C, et al (2007) Improving indoor environmental quality for public health: Impediments and policy recommendations. Environ Health Perspect 115:953957. https://doi.org/10.1289/ehp.8986

Yen YC, Yang CY, Ho CK, et al (2020) Indoor ozone and particulate matter modify the 

association between airborne endotoxin and schoolchildren's lung function. Sci Total Environ 705:135810. https://doi.org/10.1016/j.scitotenv.2019.135810

905

Zeng L, Du B, Lv L, et al (2020) Occupant exposure and ventilation conditions in Chinese 906 residential kitchens: Site survey and measurement for an old residential community in Shanghai. J Build Eng 31:101406. https://doi.org/10.1016/j.jobe.2020.101406

908 
Figures

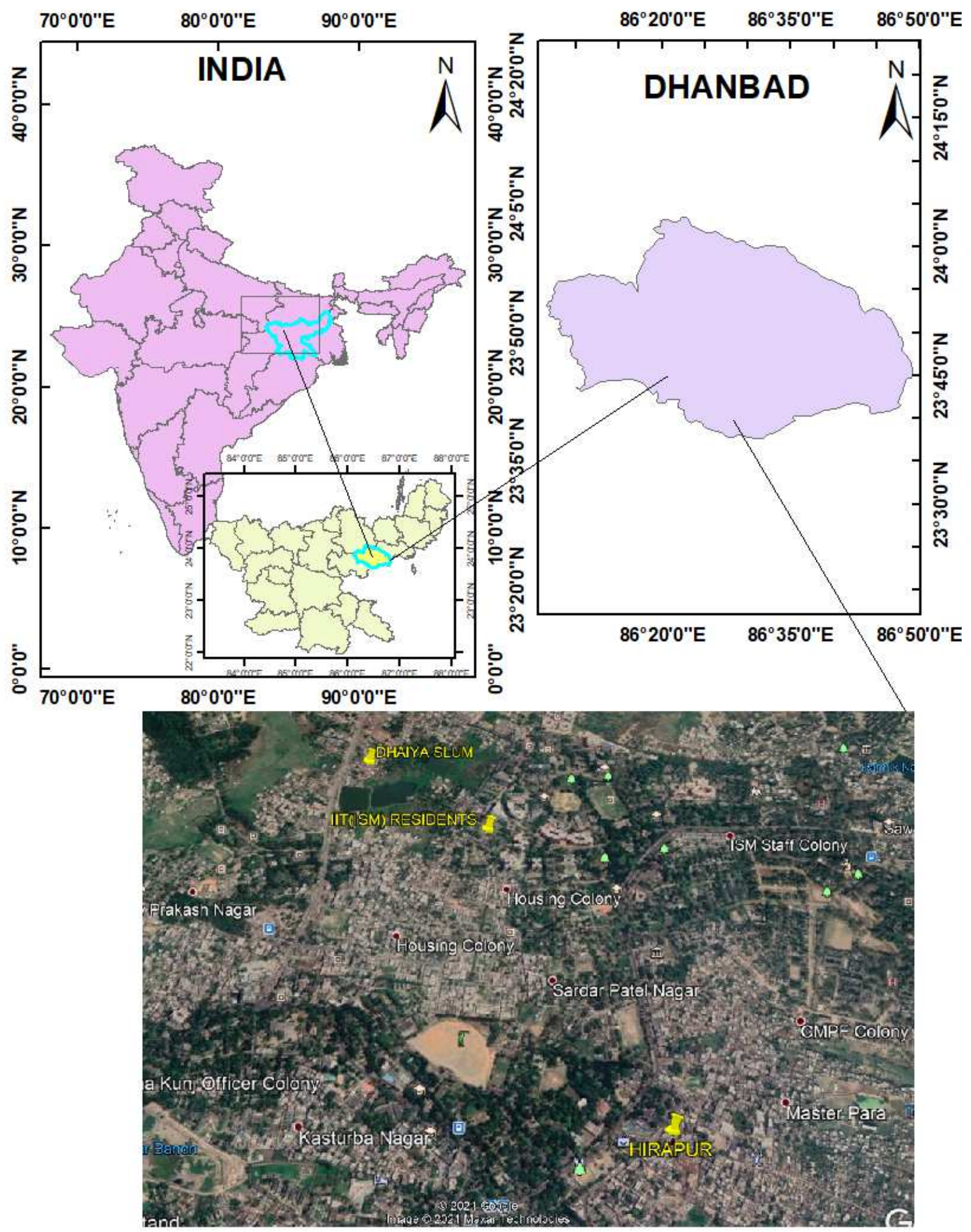

\section{Figure 1}

Study Area. Note: The designations employed and the presentation of the material on this map do not imply the expression of any opinion whatsoever on the part of Research Square concerning the legal 
status of any country, territory, city or area or of its authorities, or concerning the delimitation of its frontiers or boundaries. This map has been provided by the authors.
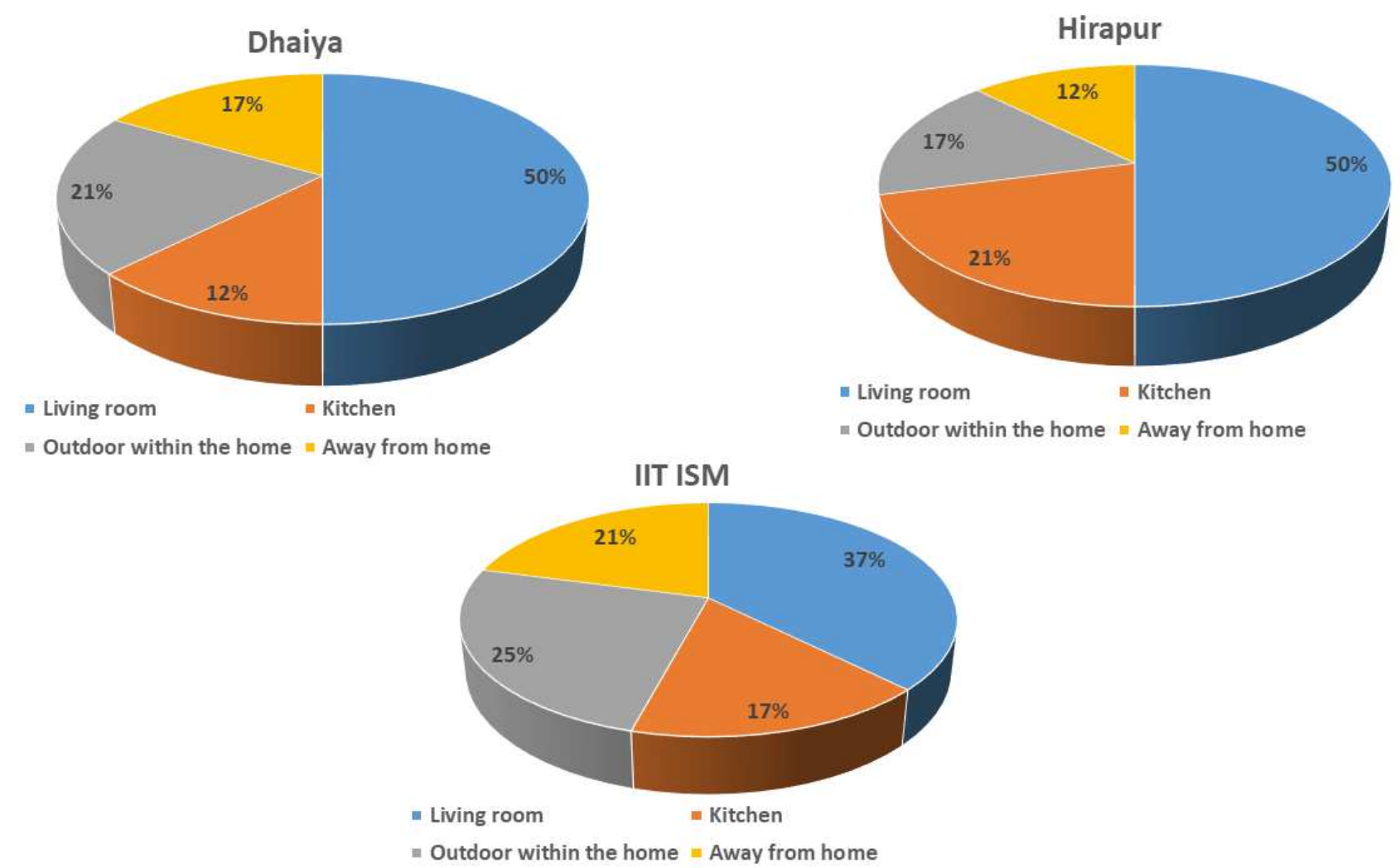

Figure 2

Time activity pattern in different locations 

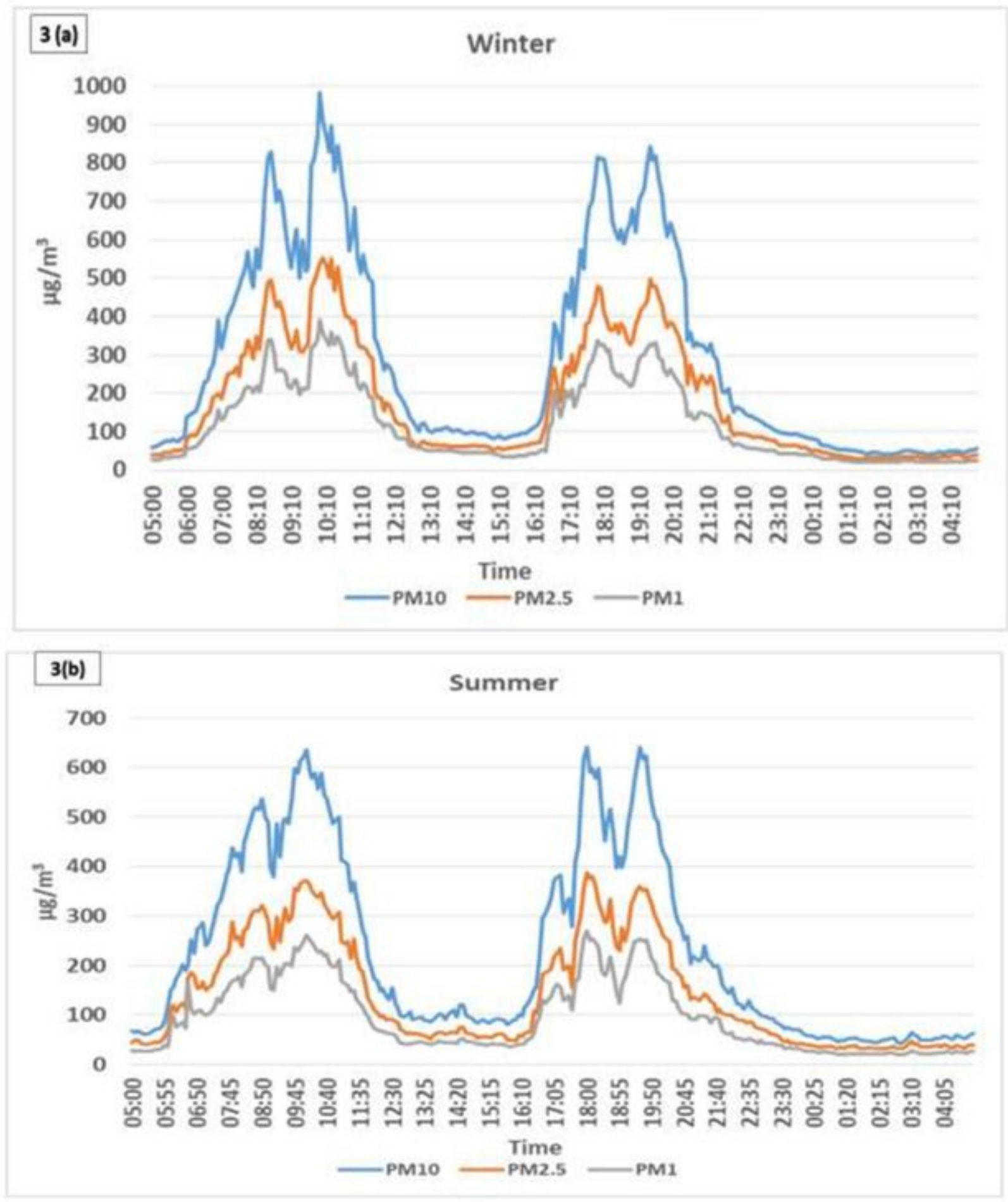

Figure 3

(a): PM variation during Winter time (b): PM variation during Summer time 


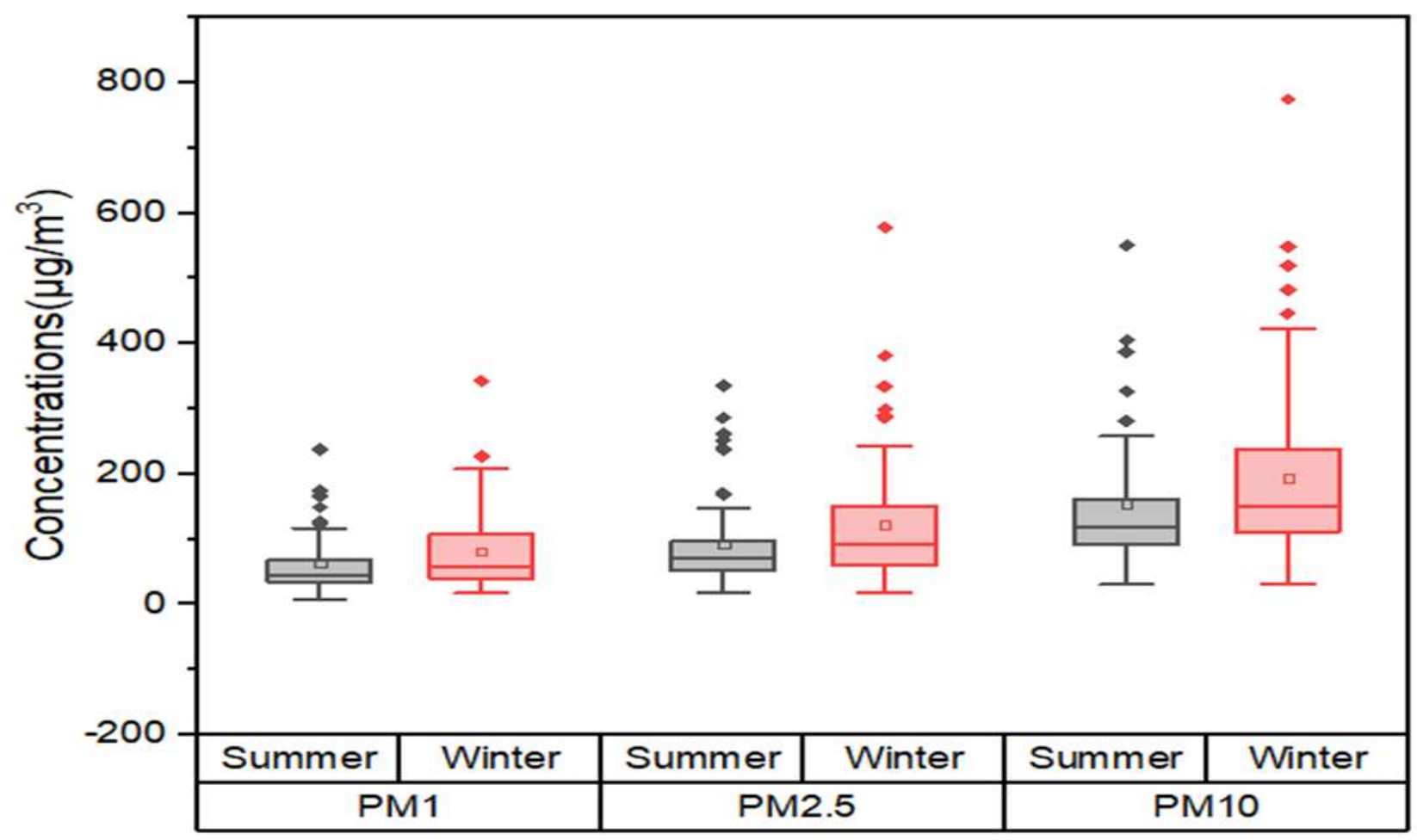

Figure 4

Seasonal variation in PM concentration

Total RDD

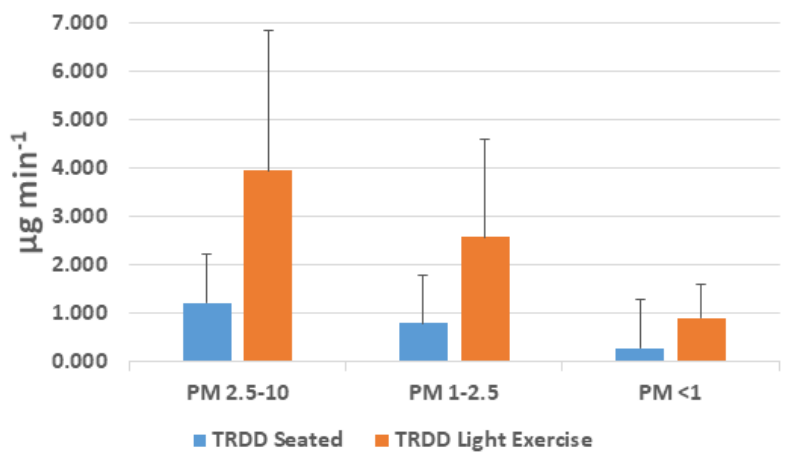

TB

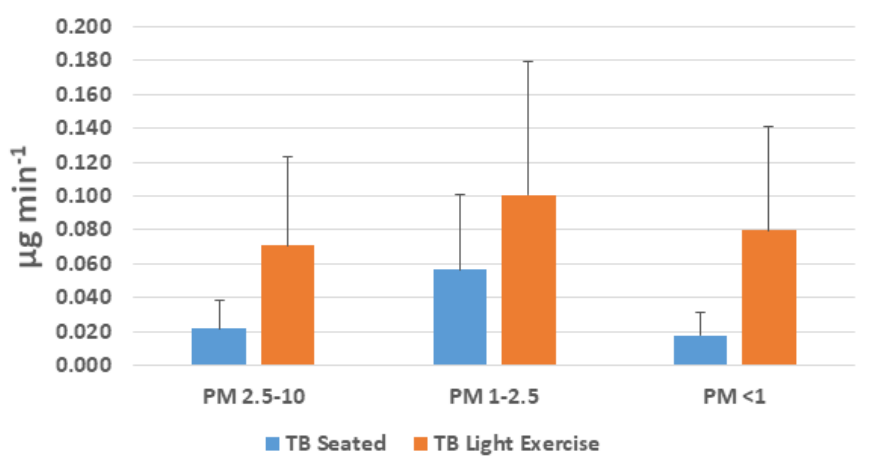

HD

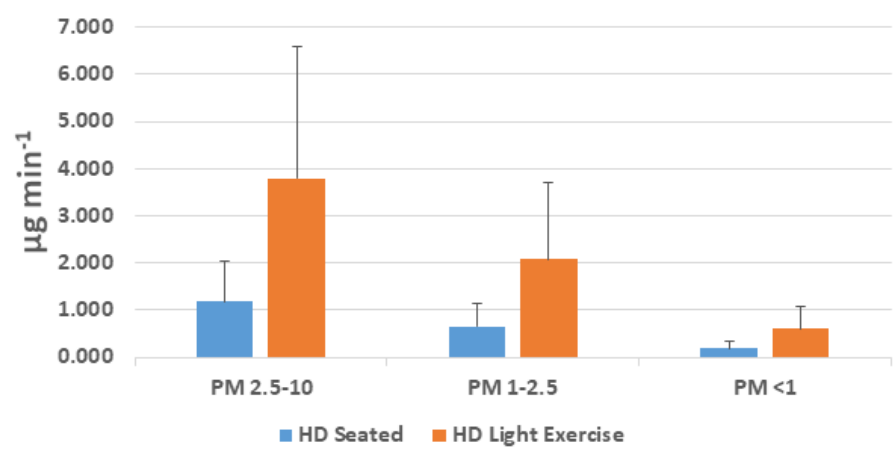

AL

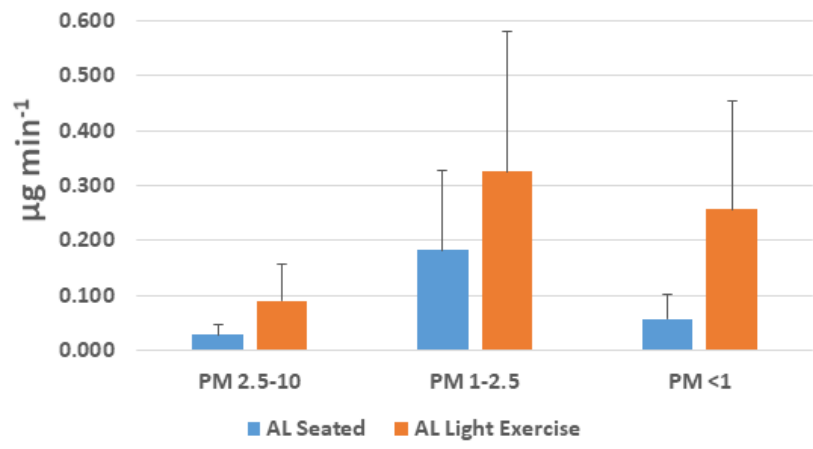




\section{Figure 5}

Rdds due to different Particles size during two different positions.

HD

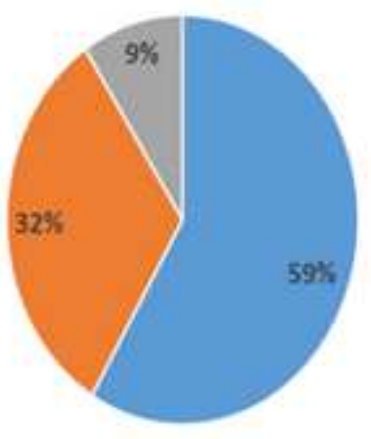

- PM2.5-10 = PM1-2.5 =PMC4
TB

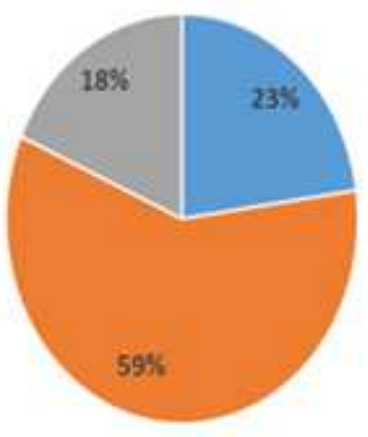

NPM 2.5.10 = PM1-2.5 IFM<:
AL

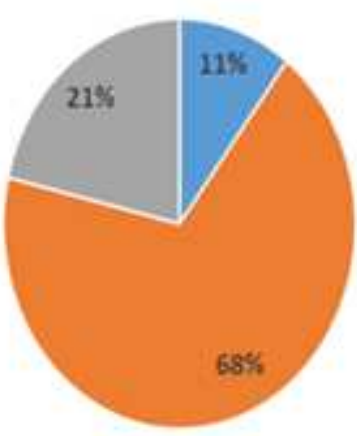

\&PM2.5-10 \& PM1-2.5 *.7M41

\section{Figure 6}

Percentage variation of Rdds values for different Particles size (PM10, PM2.5, and PM1) in different regions ( $H D$, TB and $A L)$.

Total RDD
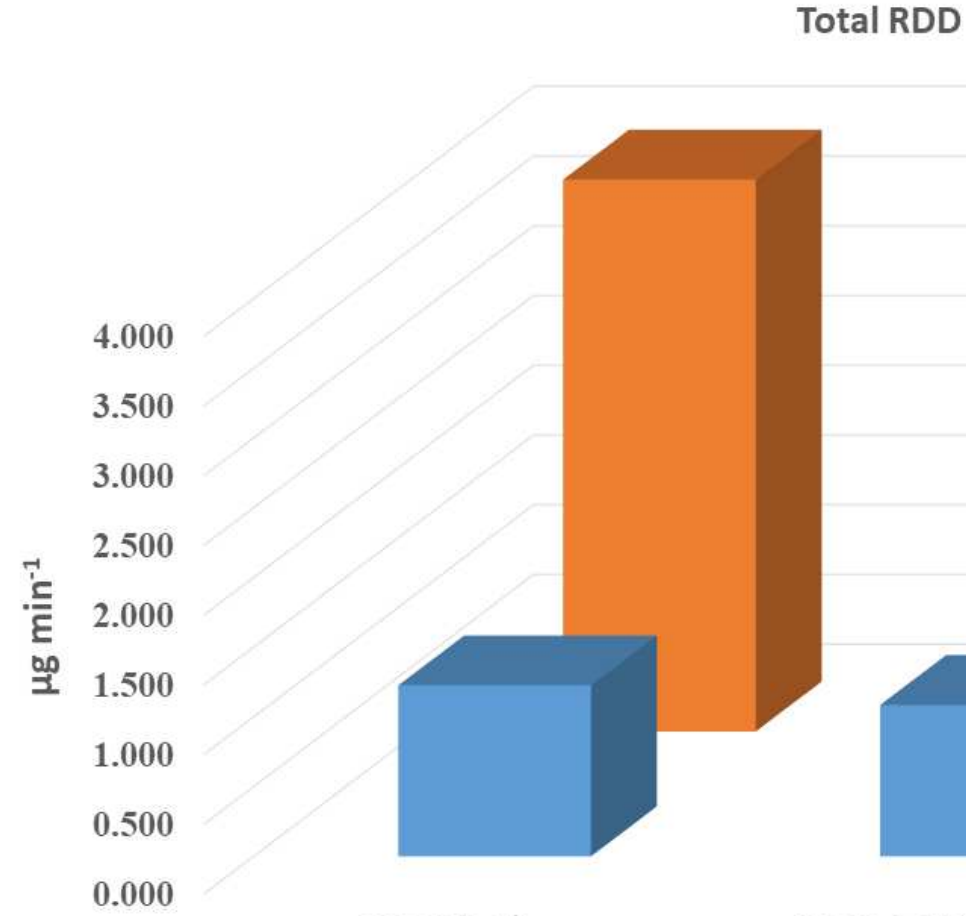

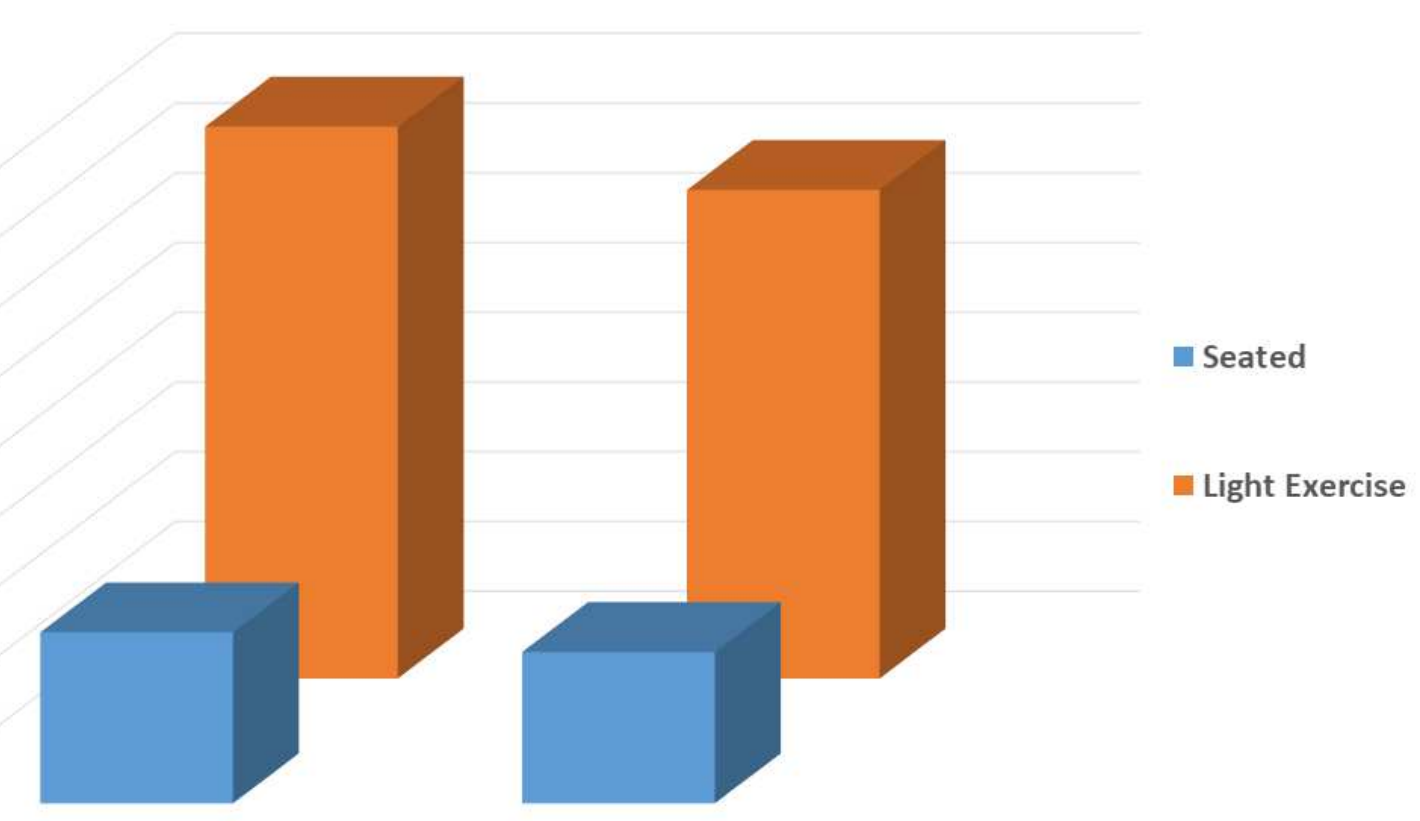

PM 2.5-10

PM1-2.5+PM $<1$ 
Rdds due to Coarser (PM10) and Fine particles (PM2.5+PM1).

12.00

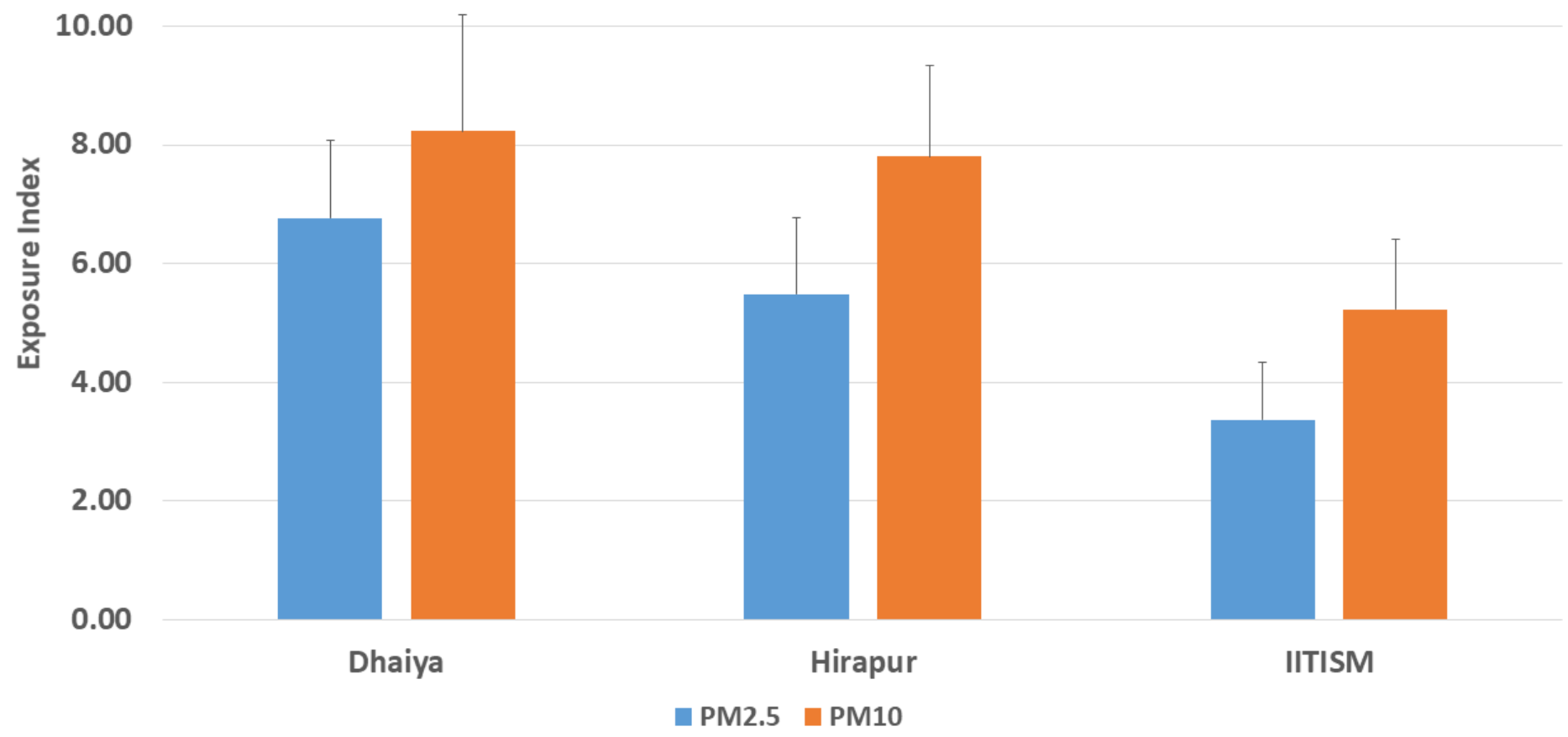

Figure 8

Exposure Index in different locations.

\section{Supplementary Files}

This is a list of supplementary files associated with this preprint. Click to download.

- SupplementaryInformation.docx 